\title{
Synthesizing published knowledge of boreal forest cover change for large-scale landscape dynamics modelling
}

\author{
by Dennis Yemshanov ${ }^{1}$ and Ajith H. Perera ${ }^{1,2}$
}

We reviewed the published knowledge on forest succession in the North American boreal biome for its applicability in modelling forest cover change over large extents. At broader scales, forest succession can be viewed as forest cover change over time. Quantitative case studies of forest succession in peer-reviewed literature are reliable sources of information about changes in forest canopy composition. We reviewed the following aspects of forest succession in literature: disturbances; pathways of post-disturbance forest cover change; timing of successional steps; probabilities of post-disturbance forest cover change, and effects of geographic location and ecological site conditions on forest cover change. The results from studies in the literature, which were mostly based on sample plot observations, appeared to be sufficient to describe boreal forest cover change as a generalized discrete-state transition process, with the discrete states denoted by tree species dominance. In this paper, we outline an approach for incorporating published knowledge on forest succession into stochastic simulation models of boreal forest cover change in a standardized manner. We found that the lack of details in the literature on long-term forest succession, particularly on the influence of pre-disturbance forest cover composition, may be limiting factors in parameterizing simulation models. We suggest that the simulation models based on published information can provide a good foundation as null models, which can be further calibrated as detailed quantitative information on forest cover change becomes available.

Key words: probabilistic model, transition matrix, boreal biome, landscape ecology

Nous avons révisé les informations publiées sur les successions forestières du biome boréal de l'Amérique du Nord pour leur applicabilité dans la modélisation des changements du couvert forestier sur de grandes superficies. À grande échelle, les successions forestières peuvent être visualisées comme des changements dans le couvert forestier au cours du temps. Les études de cas quantitatives des successions forestières dans la littérature révisée par des spécialistes du milieu représentent des sources fiables d'information sur les changements dans la composition du couvert forestier. Nous avons révisé les aspects suivant des successions forestières dans la littérature : les perturbations; les directions suivies du changement du couvert forestier après perturbation; la chronologie des étapes successives; les probabilités entourant le changement du couvert forestier après perturbation et les effets de la localisation géographique et des conditions écologiques de la station sur le changement du couvert forestier. Les résultats de ces études dans la littérature qui reposaient surtout sur les observations tirées des parcelles-échantillons, semblaient être suffisant pour décrire le changement du couvert forestier boréal comme un processus généralisé de transition par état successif, les états successifs étant marqués par la dominance des espèces d'arbres. Dans cet article, nous soulignons une approche pour incorporer les informations publiées sur les successions forestières dans des modèles stochastiques de simulation du changement du couvert forestier boréal de façon uniformisée. Nous avons constaté que le manque de détail dans la littérature sur les successions forestières à long terme, particulièrement sur l'influence de la composition du couvert forestier avant la perturbation, représentent probablement un facteur limitatif pour établir les paramètres des modèles de simulation. Nous suggérons que les modèles de simulation basés sur l'information publiée peuvent constituer une bonne base pour les modèles sans effet qui peuvent être calibrés par la suite lorsque l'information quantitative détaillée sur le changement du couvert forestier sera disponible.

Mots-clés: modèle probabilistique, matrice de transition, biome boréal, écologie du paysage

\section{Introduction}

The North American boreal forest biome covers over 420 million ha (UN-ECE/FAO 2000). This forest cover is subject to constant change, resulting in what is commonly referred to as a "shifting mosaic" (Clark 1991, Baker 1993), reflecting largescale disturbances, such as forest fire (e.g., Heinselman 1981), insect epidemics (e.g., Holling 1992), and timber harvest (e.g., Harvey et al. 1995). Given the significance of the North American boreal forest in conserving biodiversity (e.g., Roberts and Gilliam 1995) and maintaining global carbon budgets (Price and Apps 1995), consequences of forest cover change are wide-ranging and need to be better understood. Knowledge of forest cover change, especially in a quantitative and spatially explicit form, is critical for a variety of modelling tasks, including assessing productivity (Van Cleve and Viereck

${ }^{1}$ Ontario Forest Research Institute, Ontario Ministry of Natural Resources, 1235 Queen St. E., Sault Ste. Marie, ON, P6A 2E5.

${ }^{2}$ Author to whom correspondence should be sent. E-mail: ajith.perera@mnr.gov.on.ca

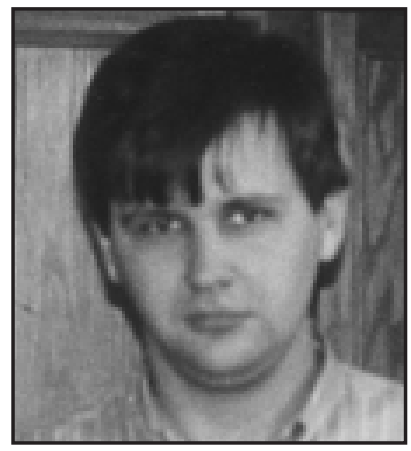

Dennis Yemshanov

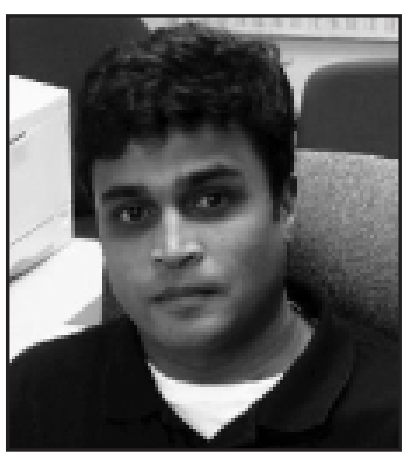

Ajith H. Perera
1981, Paré and Bergeron 1995), determining effects of disturbances (Flannigan et al. 1998, Bergeron 2000), monitoring timber supply (Bergeron and Harvey 1997), and understanding the implications of climate change (Landhausser and Wein 1993, Kasischke et al. 1995).

Natural resource managers are faced with new challenges in achieving sustainable forest landscape management in the 
boreal biome. To help them maintain natural disturbance regimes in support of sustainable timber harvesting, large-scale models that can predict forest cover change under different management scenarios and disturbance regimes are needed. However, developing a unified landscape model for the whole boreal biome is a difficult task. The published knowledge on boreal forest succession provides a starting point, by helping us to outline model structure and further calibration requirements for particular forest management areas and sub-regions. Indeed, the literature provides a variety of case studies (e.g., Viereck 1970, Dix and Swan 1971, Bergeron and Dubuc 1989, Cumming et al. 2000) and a variety of techniques to analyze and quantify forest succession (Shafi and Yarranton 1973, Heinselman 1981, De Grandprè et al. 1993, Burton and Cumming 1995, Flannigan et al. 1998).

To further the goal of developing a landscape-level boreal forest cover change model, we explored how the published data on boreal forest succession could be synthesized for landscape dynamics modelling needs.

\section{Review Of Published Data on Boreal Forest Cover Succession in North America}

More than 400 publications were selected from popular bibliographic databases, using forest cover succession as the primary criteria, with less emphasis on stand-level variables such as non-tree species, nutrient cycling, habitat supply, biomass productivity, and physiological processes. A complete list of these publications is provided in Yemshanov and Perera (2001).

Upon further review, we selected the 175 publications that provided quantitative data on forest succession based on original information from field-based studies (e.g., Dix and Swan 1971, Carleton 1982, Bergeron and Dubuc 1989, Bergeron and Danserau 1993, Viereck et al. 1993, Lavoie and Sirois 1998, Bergeron 2000), literature reviews (e.g., Heinselman 1981, Weinstein and Shugart 1983, Schmidt et al. 1996), compilations of expert opinion (e.g., Lutz 1956, Chambers 1995), and forest species inventories (e.g., Reid 1974, Wall 1982, Carleton and Gordon 1992).

\section{Representing succession for large-scale landscape modelling purposes}

In this paper, we consider the modelling of forest cover change as a probabilistic discrete state transition process, a concept that often appears in the modelling literature (Rejmanek et al. 1987, Baker 1989, Flamm and Turner 1994, Muller and Middleton 1994, Trabaud and Galtie 1996, Jin and Wu 1997, Childress et al. 1998, Logofet and Lesnaya 2000, Yemshanov and Perera 2002). Probabilistic transition models treat forest cover as a system of discrete states, where forest cover change is modelled as a replacement of these states over time. Numerically, this process can be formalized using a transition probability matrix (e.g., Horn 1975, Acevedo et al. 1995, Li 1995, Logofet and Lesnaya 2000). Future forest cover composition $W_{(\mathrm{t}+1)}$ at time interval $t+1$ can be predicted from current land cover composition at time $t$ and a matrix of transition probabilities:

$$
W_{t+1}=W_{t} \mathbf{P}_{t},
$$

where $W_{t}$ is a $1 \times n$ state vector at time $t, \mathbf{P}_{t}$ is a $n \times n$ matrix of transition probabilities consisting of $p_{\mathrm{ij}}$ values, $n$ is the maximum number of discrete states, and $p_{i j}$ gives the probability of transition from discrete state $i$ to state $j$ between time $t$ and $t+1(i, j \leq n)$ :

$$
\mathbf{P}_{t}=\left[\begin{array}{llll}
p_{11} & p_{12} & \cdots & p_{1 n} \\
p_{21} & p_{22} & \cdots & p_{2 n} \\
\vdots & \vdots & \ddots & \vdots \\
p_{n 1} & p_{n 2} & \cdots & p_{n n}
\end{array}\right] .
$$

For any given time $t(t=1,2, \ldots k)$, the transition probabilities follow these conditions:

$$
\left\{\begin{array}{l}
p_{i j}(t) \geq 0, \forall i, \in 1, \ldots N \\
\sum_{j=1}^{N} p_{i j}(t)=1
\end{array}\right.
$$

When the number of discrete steps increases, a model may converge from its initial state $\mathbf{W}_{(0)}$ into a steady state $\mathbf{W}_{(\infty)}$, limiting distribution (Karlin 1968):

$$
\mathbf{W}_{(\infty)}=\lim _{t \rightarrow \infty} \mathbf{W}_{(0)} \mathbf{P}^{t}
$$

Temporal behaviour of the transition probabilities can be addressed by considering the time $v_{i}$ when state $i$ is being replaced by state $j$ (Howard 1971). Logofet and Lesnaya (2000) used a time-dependent model, where each probability of discrete state persistence $p_{i i}$ depended on the length of time spent in state $i$ : $v_{i} \cdot p_{i i}$ was calculated from $v_{i}$ as:

$$
v_{i}=\sum_{n=0}^{\infty} p_{i i}^{n}=\frac{1}{1-p_{i i}}
$$

As a result, each discrete state has finite $v_{i}$, and for any given time interval $t, t<v_{i}$ :

$$
p_{\mathrm{ii}}=1-1 / v_{\mathrm{i}}
$$

Another approach is to consider $p_{i j}$, the probability of discrete state $i$ being replaced by state $j$, as dependent on the time spent in state $i: p_{i j}$ (Acevedo et al. 1995). The time-dependency of $p_{i j}$ can be modelled via $v_{i j}$, the lag time the model was in state $i$ until being replaced by state $j$ :

$$
v_{i j}=\sum_{i=1}^{n} p_{i j} h_{i j}(t)
$$

Here, $v_{i j}$ represents the sum of lag time densities $h_{i j}$ for each time interval $t, t<v_{i j}$, and corresponding transition probabilities $p_{i j}$. The lag time densities $h_{i j}(t)$ of transition from state $i$ to $j$ can be found for each time interval $t, t<v_{i j}$, by fitting them to a probability distribution function (Acevedo et al. 1996).

Discrete-state transition models have been used to predict vegetation succession and land cover change at various spatial extents: i.e., from individual species to landscape-scale patterns 


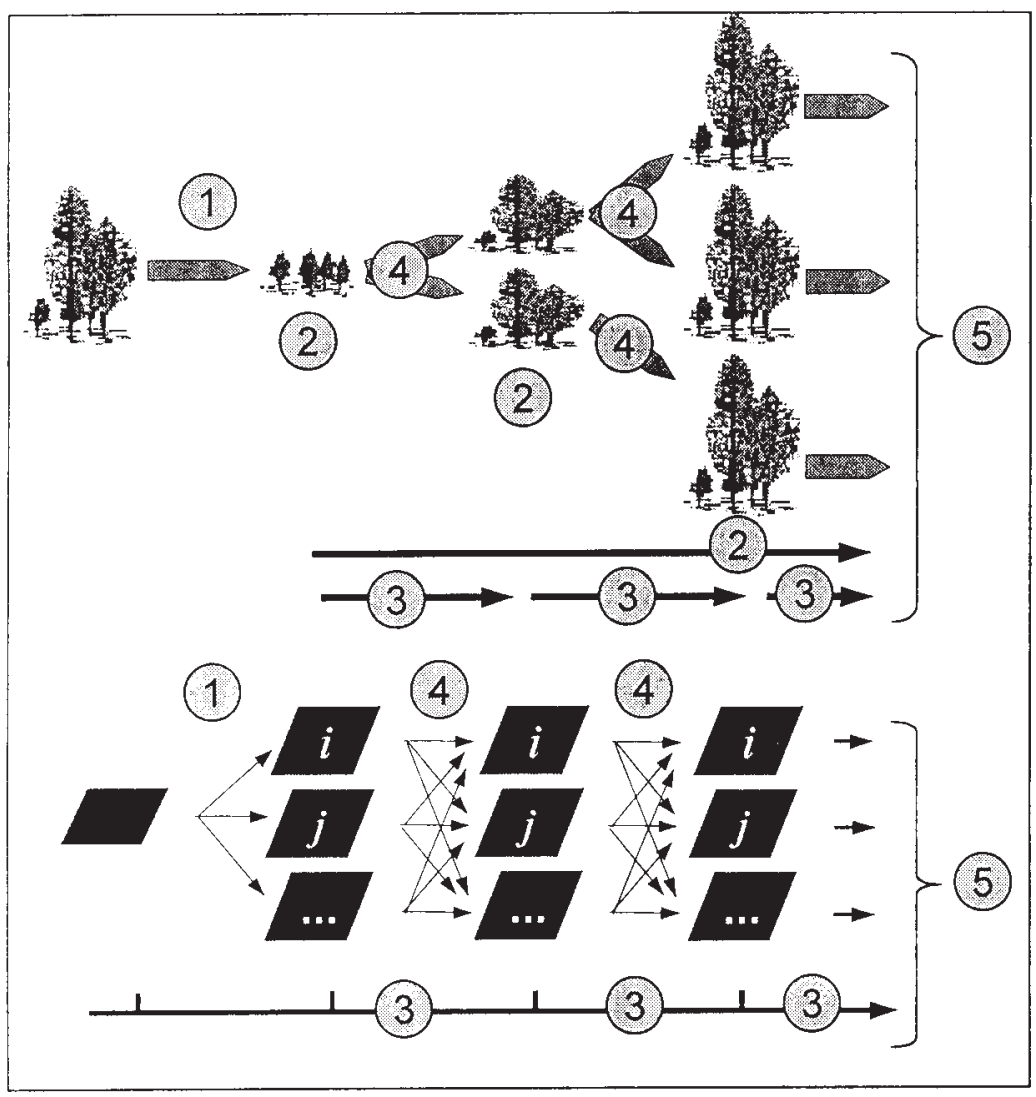

Fig. 1. Knowledge required to conduct forest succession modelling at large scales: 1 - Initial conditions; 2 - Post-disturbance pathways; 3 - Temporal details; 4 - Probabilities of forest cover change; 5 - Effects of geographic location and ecological site conditions; $i, j$ - discrete states.

(Horn 1975, Bellefleur 1981, Rejmanek et al. 1987, Baker 1989, Muller and Middleton 1994, Trabaud and Galtie 1996, Childress et al. 1998). Although these transition models require fewer parameters than the stand-level gap models (Urban et al. 1999), they still require data to derive transition probabilities and model structure (i.e., time-dependent, or first-order, definition of discrete states). One convenient source of such data is the published literature. However, the use of published literature requires that several issues be considered:

The first issue relates to information about the scale of the process. At large scales, the process of forest succession does not closely match that of stand succession in its strictest sense (e.g., Spurr and Barnes 1980) nor the tree-by-tree replacement process (e.g., Horn 1981), but addresses the change in forest cover at coarse spatial resolution. Overall, forest succession information can be categorized into five basic groups that are relevant to developing models of forest cover change (Fig.1):

- Initial conditions include the effects of previous disturbances and the pre-disturbance forest cover composition on postdisturbance forest cover change (Fig. 1-1);

- Pathways of post-disturbance forest cover change describe the possible successional trajectories at the level of species composition in the canopy or forest classification unit (Fig. 1-2);

- Temporal details include aspects of succession such as periods of species persistence in the canopy and timing of successional steps. (Fig. 1-3);

- Probabilities of post-disturbance forest cover change refer to characterizing successional phases that can be depicted with discrete states, using a probabilistic process. For example, a simple sequence of successional phases, such as
$\mathrm{A}->\mathrm{B}$, assumes that the probability of $\mathrm{B}$ replacing $\mathrm{A}$ equals 1. Any other ramifications, e.g., $C<-A->B$, lead to the probabilistic process (Fig. 1. 4); and

- Effects of geographic location and ecological site conditions on forest cover change can be spatially linked using detailed descriptions of geographical location and ecological site conditions in field case studies (Fig. 1-5).

The second issue relates to the discrete states in a transition model required to adequately portray forest cover change in a landscape. The choice of discrete states must correspond to the available spatial data. For example, when forest cover data are derived from classified satellite imagery, only broad classes of canopy composition can be distinguished. In this case, direct use of stand-level field knowledge of succession to develop discrete state models is not an option.

The use of tree species dominance in the canopy to define the discrete states may be appropriate when forest communities have simple canopy structures and low tree species diversity. For example, in the boreal biome succession is often reported as dominant tree species replacement in the canopy (e.g., Viereck 1973, Neiland and Viereck 1977, Woods and Day 1977, Bergeron and Dubuc 1989, Morneau and Payette 1989, Bergeron 2000, De Grandprè et al. 2000). In addition, the specific autecological responses of boreal tree species to disturbances have been widely studied (e.g., Heinselman 1981, Sims et al. 1990, Payette 1992) and can be used to separate early from late-successional stages.

Tree species dominance can be easily recognized and measured directly through field studies (Carleton 1982, Johnson and Fryer 1987, Viereck et al. 1983) or indirectly through aerial photograph interpretation over large areas (Jeglum and Boisson- 
Table 1. Succession papers available in the literature categorized by spatial scale and disturbance type studied

\begin{tabular}{|c|c|c|c|c|c|c|c|}
\hline \multirow{2}{*}{$\begin{array}{l}\text { Disturbance type } \\
\text { Spatial scale }\end{array}$} & \multicolumn{2}{|c|}{ Fire } & \multicolumn{2}{|c|}{ Natural ageing } & \multicolumn{2}{|c|}{ Harvest } & \multirow[b]{2}{*}{ Total } \\
\hline & Species & Forest type & Species & Forest type & Species & Forest type & \\
\hline Individual tree & - & - & 3 & - & 8 & - & 11 \\
\hline Stand & 39 & 7 & 28 & 2 & 18 & - & 94 \\
\hline Forest classification unit & - & 2 & - & - & - & - & 2 \\
\hline Landscape & - & - & - & 2 & - & - & 2 \\
\hline Total & 39 & 9 & 31 & 4 & 26 & - & 109 \\
\hline
\end{tabular}

neau 1977, Sayn-Wittgenstein 1978). Using dominant tree species as descriptors of boreal forest cover change is also advantageous because of its compatibility with operational spatial data sources, such as forest resource inventories (e.g., Gillis and Leckie 1996).

However, the use of dominant species to define discrete states is appropriate only when dominance can be easily recognized in the canopy and associated with specific successional stages. For the special case of mixedwood forest types, where the dominance cannot be clearly recognized, a different approach can be used. For example, synthetic forest classification units (FCU) may be applied as discrete states of the model. FCUs are useful for forest management, where they are used to distinguish forest stands based on canopy species composition and ecological site conditions (OMNR 1996).

The third issue is the spatial resolution used for modelling. Tree species dominance is resolution-sensitive. When the spatial resolution of a model corresponds to individual trees (e.g., $0.01-0.1$ ha), single-tree dominance criteria can be used. For coarser spatial resolution (e.g., 1 ha), when the probability of species mixtures in the canopy may increase, it may be necessary to develop special FCUs based on canopy species combinations. In addition, constraints such as resolution of forest inventory databases must be considered when defining discrete states.

\section{Information on forest cover change in the literature}

We reviewed 175 publications for relevant modelling information that they could provide as discussed above. Of these, 109 contained data representing succession in terms of tree species dominance or other coarser-scale categories such as forest ecosystem classification units (see Appendix 1). Over 50\% of these reported successional process in textual form, using dominant species at discrete stages of succession as qualitative descriptors (e.g., Viereck 1973, Neiland and Viereck 1977). Another $20 \%$ presented succession in graphical form, illustrated by either line graphs of the process or forest profiles (e.g., Johnson and Rowe 1977, Viereck 1983). Only about one third of the reports included quantitative data on succession, such as relative species abundance over time (Bergeron and Dubuc 1989, Lavoie and Sirois 1998, Bergeron 2000).

Most studies (86\%) focused on forest stands (Table 1), with only a few $(2 \%)$ reporting succession processes at larger spatial extents.

Below, we describe the published knowledge on forest cover change using five categories (Fig. 1).

Initial conditions: The type and characteristics of disturbances that initiated succession were well documented by most field case studies (Black and Bliss 1978, Heinselman 1981, Bergeron and Dubuc 1989, Johnson and Fryer 1987, Payette et al. 1989, De Grandprè et al. 2000). Natural disturbance history of the boreal forest has been reconstructed using various meth- ods, primarily from dendroecological data (Bergeron and Charron 1994) and historical inventories (e.g., Payette et al. 1989, Bergeron and Danserau 1993, De Grandprè et al. 2000). Historical aerial photographs and inventories also provide references to past clearcuts, fires, windthrow events, and insect outbreaks (Arseneault 2001). However, the question of how disturbance severity affects forest cover change at large scales remains unclear (Zasada et al. 1987, Landhausser and Wein 1993).

Pathways of post-disturbance forest cover change: This parameter is also well documented, although it is represented in different ways in the literature. The three most common representations are:

- Textual data describing forest succession as a phased sequence based on disturbance type, severity, and the time since the disturbance (e.g., Ritchie 1956, Zoltai 1975, Bertrand et al. 1992);

- Visual representation of succession as a scheme or pathway graph. Usually, the sequence of discrete states is reported in a deterministic way without any reference to probabilities of occurrence (e.g., Johnson and Rowe 1977, Viereck 1983); and

- Quantitative data showing changes in forest composition over time, e.g., forest composition, species abundance, basal area, biomass, stem density (Bergeron and Dubuc 1989, Viereck et al. 1993, Lavoie and Sirois 1998, Bergeron 2000).

Most of the knowledge is reported at the stand scale; very few studies assess succession at larger scales (e.g., Weinstein and Shugart 1983, White and Mladenoff 1994, Schmidt et al. 1996, Zhang et al. 1999).

Information on pre-disturbance vs. post-disturbance forest cover change is of practical interest for modelling post-disturbance forest cover dynamics. Quantitative data comparing pre- and post-disturbance forest cover composition are rare in the literature (e.g., Delaney and Cahill 1978, Bergeron and Gagnon 1987, Thomas and Wein 1985, Sirois and Payette 1989). Indirect references to this type of data were found in some successional schemes and pathway diagrams (e.g., Lutz 1956, Viereck 1973, Neiland and Viereck 1977). Sometimes the description of pre-disturbance forest composition has been generalized (e.g., Jarvis 1960) or simplified to the few most typical forest classification units (e.g., Heinselman 1981). Some papers also reported pre-disturbance vs. post-disturbance forest composition for only short-term studies of early post-disturbance establishment (e.g., Methven 1973, Chrosciewicz 1988). Many studies that reported post-disturbance successional pathways did not provide details on pre-disturbance vs. post-disturbance forest composition (e.g., Day and Harvey 1981, Heinselman 1981, Carleton 1982, Foote 1983, Bergeron and Dubuc 1989, Payette 1992). However, authors of the more recent studies (e.g., Cumming 2001, Arseneault 2001) emphasized that pre-disturbance conditions could initiate different successional pathways of post- 
Table 2. Succession papers in the literature classified by number of successional phases and duration of study for each disturbance type

\begin{tabular}{|c|c|c|c|c|c|c|c|c|c|c|c|c|c|c|c|c|c|c|c|c|c|c|c|c|}
\hline \multirow[b]{3}{*}{$\begin{array}{l}\text { Successional } \\
\text { phases } \\
\text { (number) }\end{array}$} & \multicolumn{24}{|c|}{ Duration succession studied (years) } \\
\hline & \multicolumn{8}{|c|}{ Fire } & \multicolumn{8}{|c|}{ Natural aging } & \multicolumn{8}{|c|}{ Harvest } \\
\hline & $\stackrel{1}{1}$ & î & î & $\frac{8}{9}$ & 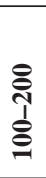 & હે̊ & 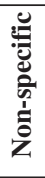 & 预 & $\stackrel{1}{1}$ & กิ & 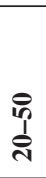 & $\underset{8}{8}$ & $\begin{array}{l}\stackrel{8}{1} \\
\stackrel{1}{8}\end{array}$ & 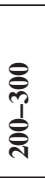 & 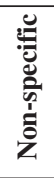 & 丞 & $\stackrel{1}{1}$ & î & î & $\frac{8}{8}$ & 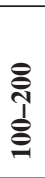 & ஓ్̊ & 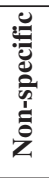 & 焉 \\
\hline $1-2$ & & 1 & 2 & 1 & 2 & 1 & 1 & 8 & & 5 & & 1 & 1 & 1 & 2 & 10 & 2 & 5 & 1 & & 1 & & 1 & 10 \\
\hline $3-4$ & 2 & 1 & 1 & 2 & 1 & 3 & 4 & 14 & & & & 1 & 1 & & 2 & 4 & 3 & 3 & & & & & & 6 \\
\hline $5-7$ & & & & 1 & 5 & 2 & 1 & 9 & & & & 1 & & 1 & 1 & 3 & & & & 1 & 1 & & & 2 \\
\hline $8-11$ & & & & & & 3 & & 3 & & & & & 1 & 3 & & 4 & & 1 & & & & & & 1 \\
\hline Non-specific & 2 & 1 & 1 & & 2 & 1 & 7 & 14 & & & 1 & & & 3 & 10 & 14 & & 3 & & & & & 4 & 7 \\
\hline
\end{tabular}

*Shading indicates data with 20-year or better temporal accuracy

fire succession in the boreal forest. While published studies on post-fire forest succession and long-term succession due to natural ageing were frequent, long-term quantitative information about natural ageing following harvest was lacking.

Temporal details: It was important to determine the number of discrete successional phases that can be extracted from published data. Most papers provided stages of succession (Viereck et al. 1993) or changes in composition of dominant tree species over post-disturbance time (e.g., Bergeron and Dubuc 1989, Chambers 1995, Bergeron 2000, De Grandprè et al. 2000). Regardless of disturbance type, most studies reported five or less distinct successional stages (Table 2).

Other temporal details on forest cover change at larger scales found in the literature included forest cover composition and the dates of consecutive studies (Van Cleve and Viereck 1981, Weir and Johnson 1998), generalized schemes of largescale forest cover replacement (e.g., Pastor and Mladenoff 1992), and time steps of forest cover transitions (Weir and Johnson 1998, Zhang et al. 1999).

Also important was the temporal accuracy for different lengths of successional periods. Because most landscape models predict forest cover change with 10- to 20-year time steps (Baker 1999, He and Mladenoff 1999), this time interval can be used as a guideline for a data search of the literature. We determined how well temporal details on succession can be used in landscape modelling as follows: Papers with quantitative successional data were categorized by the duration of succession reported and the number of successional stages that were referenced or could be extracted from reported data. Then the data range with 20-year or shorter intervals was identified (Table 2, shaded). The literature was most detailed for post-fire succession, whereas the temporal details for post-harvest and natural ageing succession were less detailed. Also, post-fire succession has been studied for periods longer than other types of disturbance in the boreal biome. However, most reports that provided successional data beyond 200 years were less detailed than shortterm studies.

Successional time variables (i.e., persistence times of specific successional phases, timing of replacements) also varied greatly (Table 2). This variation may be partially explained by the influence of early post-disturbance conditions on successional pathways (Cumming 2001). The lack of data on historical low-severity disturbances adds uncertainty to estimates of successional pathways. Our literature review also revealed the difficulties of estimating the severity of historic burns and finding evidence of the post-fire residual stand, where data on low-severity fires were reconstructed mostly from fire scars and tree rings (Danserau and Bergeron 1993, Johnson et al. 1998).

Probabilities of post-disturbance forest cover change: Standlevel studies on boreal forest succession did not mention probabilities of forest cover change (Johnson and Rowe 1977, Neiland and Viereck 1977, Viereck 1983) but rather assumed that they were deterministic replacements. Only a few recent papers on large-scale forest cover change presented the probabilities of forest cover replacement (White and Mladenoff 1994, Weir and Johnson 1998, Zhang et al. 1999).

Effects of geographic location and ecological site conditions on forest cover change: Abiotic factors, such as climate, significantly control the structure of boreal forest ecosystems (Viereck et al. 1983, Bergeron and Dubuc 1989, Bonan and Shugart 1989, Hogg 1994). Our review indicated that the literature provides adequate description of the geographic and site ecological conditions and their relation to forest cover change. Fig. 2 illustrates the geographical distribution of field case studies across North America reported in the literature we reviewed. Almost half of these were post-fire studies (Table 2).

Traditionally, successional pathways were represented by common ecosite types (Carleton et al. 1985, Hogg 1994), grouped by moisture, soil richness (Ritchie 1961, Bergeron and Dubuc 1989, Heinselman 1981, Kneeshaw and Bergeron 1996), and basic terrain features (e.g., uplands, lowland, river valleys; Heinselman 1981, Jeglum 1983, Host et al. 1987). The effect of ecological site conditions can be determined by comparing successional pathways among different site types and geographical locations. Another important spatial characteristic is the breadth of geo-climatic conditions and site types reported in the studies (Table 3). In general, the case studies reported fewer than five different ecological site types.

Some papers address succession for areas adjacent to the southern boundary of the boreal biome, e.g., the Great Lakes-St. Lawrence forest (e.g., Heinselman 1973, 1981; Woods and Day 1976, 1977). These studies were included for consideration only if they provided data about the succession of tree species common in the boreal zone.

In addition, we also found papers that reported the effects of landscape fragmentation on forest cover change in other temperate forest zones (Zipperer et al. 1990, Li et al. 1993, Mladenoff et al. 1993, Malanson and Cairns 1997). Many biotic agents of forest succession, e.g., seed dispersal (Zasada et al. 1992, Greene et al. 1999) and re-colonization of disturbed areas (Kneeshaw and Bergeron 1996, Galipeau et al. 1997), have a 


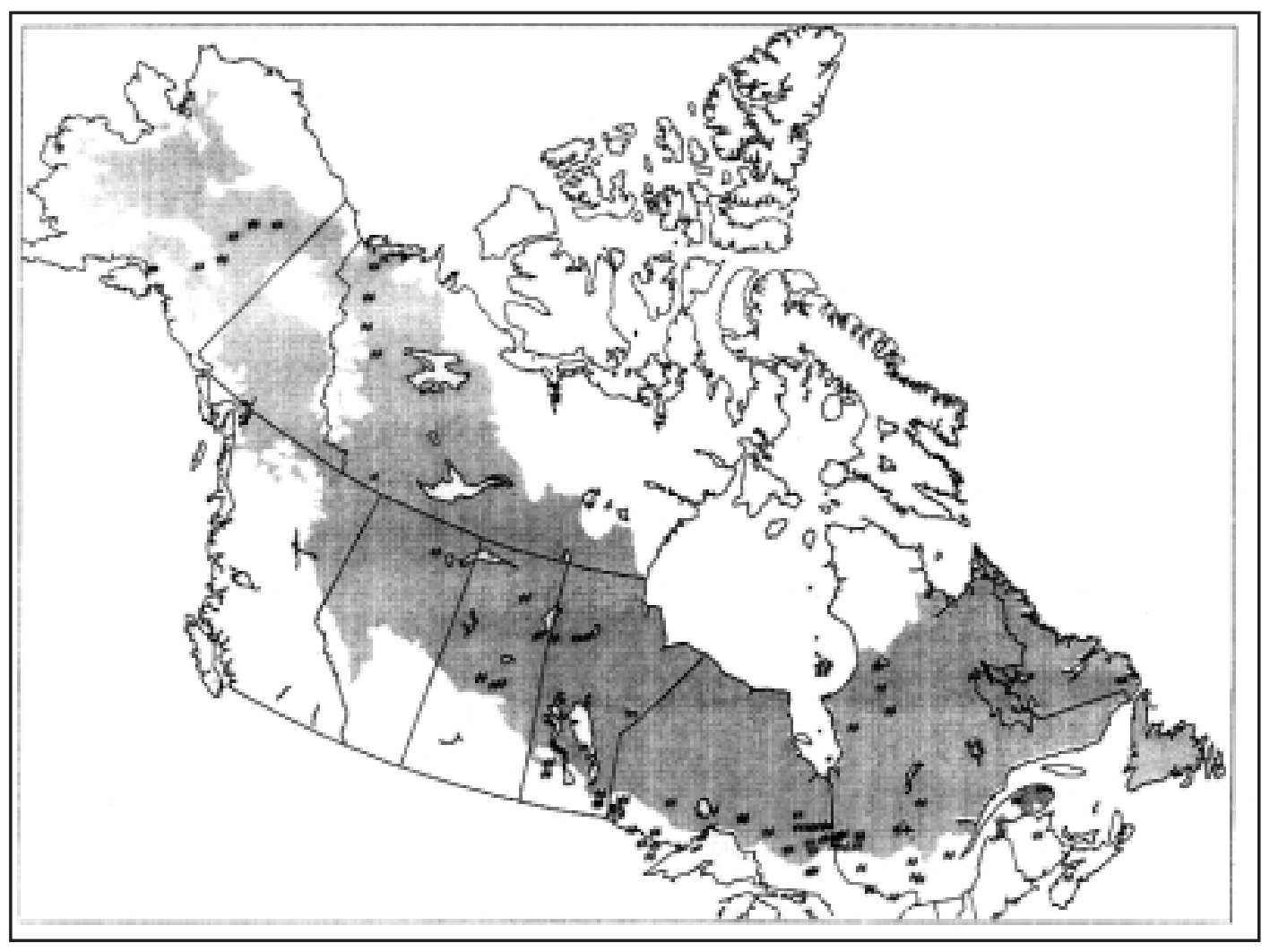

Fig. 2. Geographical distribution of case studies selected from the literature to provide input data for the forest cover transition model. Shading represents boreal zone.

Table 3. Succession papers in the literature categorized by disturbance type and number of specific site conditions studied.

\begin{tabular}{|c|c|c|c|c|c|c|c|}
\hline Type of disturbance & 1-2 groups & 3-4 groups & 5-7 groups & 8-11 groups & $>11$ groups & Non-specific & Total \\
\hline Natural ageing & 24 & 5 & 1 & - & 2 & 16 & 48 \\
\hline Fire & 3 & - & - & 1 & 2 & 6 & 12 \\
\hline Fire and natural ageing & 5 & 7 & 1 & 3 & 2 & 5 & 23 \\
\hline Harvest & 10 & 1 & 3 & 1 & 3 & 3 & 21 \\
\hline Harvest and natural ageing & 1 & 1 & - & 1 & - & 1 & 4 \\
\hline Harvest and fire & - & 1 & - & - & - & - & 1 \\
\hline Total & 43 & 15 & 5 & 6 & 9 & 31 & 109 \\
\hline
\end{tabular}

spatial component. Some, such as distance from seed source, size of disturbance, and post-disturbance forest cover pattern, have already been used in studies of forest cover dynamics (Clark 1991, Pastor et al. 1999).

\section{Use Of Published Knowledge on Succession in Large-scale Landscape Modelling}

As indicated above, existing knowledge about boreal forest succession provides only generalized information on forest cover change. However, in order to build a transition model of forest cover change, we need adequate information for the development of transition probability matrices $\mathbf{P}_{t}(\mathrm{Eq} .2)$ for given geographical locations and site conditions. As forest cover change is considered a time-dependent process (sensu Acevedo et al. 1995, Urban et al. 1999, Logofet and Lesnaya 2000), the assumptions of time dependence of $p_{i i}$ or $p_{i j}$ (Eqs. 5-7) would require additional parameters from the literature. To maximize the utility of the information in the literature, we examined the following approaches of synthesizing successional knowledge into a transition probability matrix:

- Using raw multi-temporal data (i.e., measurements of species composition for study sites) or proportions of successional phases versus successional time;
- Using outputs from fine-scale individual-based (gap) models of forest dynamics as a data generation engine; and

- Using data representing a mixture of semi-quantitative estimates, textual citations and expert opinion on succession.

These approaches are discussed in detail below.

\section{Using raw multi-temporal and proportional data}

This technique generates transition matrices with $p_{i j}$ directly from multi-temporal field-collected data (e.g., chronosequences of permanent plots, forest cover maps, satellite images, and aerial photographs). For each discrete time interval, $\Delta t$, transition probabilities can be calculated from the transition frequencies $z_{i j}$ of replacement from discrete state $i$ by state $j$ during $\Delta t$ :

$$
p_{i j}=\frac{z_{i j}}{\sum_{j} z_{i j}}
$$

This approach is common in studies of change detection in landscapes (Childress et al. 1998, Zhang et al. 1999) and vegetative composition (Balzter 2000). Since non-summarized raw spatial data are used in the calculation of $p_{i j}$, this technique produces the least biased results. 
Sometimes, the only successional data available relate to the change of proportions between discrete states over time. Common examples are historical inventory records of forest canopy composition (Reid 1974) and summaries of species composition change over post-disturbance time (Black and Bliss 1978, Bergeron 2000). These data permit determination of approximate values of transition probabilities via optimization procedures using linear programming. The $p_{i j}$ values are constrained to the interval $[0 ; 1]$ and attempt to reproduce input data proportions (more details can be found in Lee et al. 1970, Usher 1992, and Balzter 2000). Only proportion data (relative composition of specific forest cover types and their changes at certain time intervals) are needed to derive the transition probabilities, and these data are readily available in the literature. For example, canopy species composition change diagrams (e.g., Bergeron 2000) can be used to define these proportions. However, this technique assumes that transition probabilities do not change over time (i.e., first-order Markovian), and, therefore, does not account for the time-dependent nature of post-disturbance forest cover change.

\section{Using stand-level gap models as a data generation engine}

Another approach is to use finer-scale (patch- and individual-based) mechanistic models of forest succession to generate the successional pathways or chronosequences of forest canopy composition. Successional data in the literature have been widely used to design and calibrate individual-based (gap) models of forest dynamics (Bugmann 1996, Kienast et al. 1999, Mailly et al. 2000). In fine-scale gap models, stand development is simulated within sample plots by calculating establishment, growth, and death of individuals as deterministic processes. The model outputs resemble inventory tally sheets with characteristics of individual trees. These outputs can be scaled up to the forest cover level and used to parameterize large-scale probabilistic models (Acevedo et al. 1995, Urban et al. 1999).

This approach uses gap model outputs as surrogate "experimental" data to calculate transition probabilities. Acevedo et al. (1996) described the parameterization of a time-dependent transition model from simulated outputs of a spatially explicit version of the ZELIG stand-scale model (Urban and Shugart 1992, Urban et al. 1999). The technique requires a thorough calibration of gap models for large areas. The ecological factors included in most gap models vary greatly (Bugmann et al. 1996). The latest gap models have tended to replace simple combinations of climate-dependent and climate-independent processes with increasingly detailed formulations (Lexer and Hönninger 2001). However, few studies were found that evaluated the significance of how these new formulations improve the prediction of long-term forest dynamics (i.e., Bugmann and Martin 1995).

\section{Using semi-quantitative data to define the structure of the transition model}

The previous two approaches require detailed data sets or wellcalibrated stand-level successional models for large regions. Many of the data found in the literature provided only a semiquantitative outline of succession, for example, pathways or timing. This information may be insufficient for direct calculations of transition probabilities. Instead, it can be used to define the structure of the transition model, i.e., the temporal bound- aries of forest cover change (when cover replacement begins and ends, and when the maximum cover value is reached) and the discrete states, and to differentiate forest cover change by combinations of ecological site conditions. To derive transition probabilities from these limited data, assumptions of how transition probabilities would behave within the defined temporal boundaries must be used. These assumptions can be derived from published case studies and knowledge of tree species autecology. Species tolerances to disturbance or age dependency of tolerance are examples of such assumptions.

\section{Defining a time-dependent transition model from published data}

We suggest that the following approach can be used to synthesize published data on boreal forest succession for use in large-scale forest cover change modelling. Two assumptions have to be made: First, large-scale change in boreal forest cover can be described in terms of canopy-replacing transitions, and, therefore, certain canopy composition types can be used as discrete-state descriptors (single species or species mixtures). Second, the probability of tree species dominance is dependent on the time spent by the current species at a given location (this probability follows the age-dependent nature of forest canopy replacement). Thus, the probability of discrete state persistence $\left(p_{i i}\right)$ can be described by the probability distribution function $\xi(t)$ :

$$
p_{i i}(t)=\xi(t) p_{i i}
$$

The next step is fitting of $\xi(t)$ into the temporal boundaries of succession, i.e., forest cover persistence times, and the shape of the $\xi(t)$ curve. Data from the literature are insufficient to define the shape of $\xi(t)$ exactly; however, they provide at least two temporal parameters of forest cover persistence (Fig.3):

- Maximum period of forest cover persistence under the given site conditions $t_{p}$

- The time interval, $t_{d}$, since forest cover establishment, when the probability of forest cover replacement by another cover type approaches 0 .

By associating discrete states of the transition model with tree species dominance, $t_{p}$ and $t_{d}$ can be extracted from the literature. These time periods are measured using time since the current discrete state occupied a given location.

The temporal behaviour of $p_{i i}$ within the intervals $t_{d}$ and $t_{p}$ (i.e., the shape of $\xi(t)$ curve) can be characterized by the time when the rate of current forest cover replacement reaches its maximum, $t_{\text {peak }}$. Assuming $p_{i i}(t)=\xi(t) p_{i i}$ at any time within $\left[t_{d} ; t_{p}\right]$, (Eq. 9), the values $1-p_{i i}$ for each discrete time step can be found by fitting the cumulative probability density function $\xi(t) p_{i i}$ to the time constraints $t_{d}$ and $t_{p}$ taken from the literature (Fig.3). A Gamma probability density function can be used following Howard (1971):

$$
h_{i j}(t)=\frac{d_{i j}^{k_{i j}} t^{k_{i j}-1} \exp \left(-d_{i j} t\right)}{\left(k_{i j}-1\right) !},
$$

where $d_{i j}$ is a first-order rate, $k_{i j}$ is the order of the function, $t$ is the lag time, and $h_{i j}(t)$ is the lag time density for replacement of $i$ by $j$. The maximum of Gamma probability density function $h_{i j}(t)$ can be determined from $t_{\text {peak }}$. For each state, the param- 


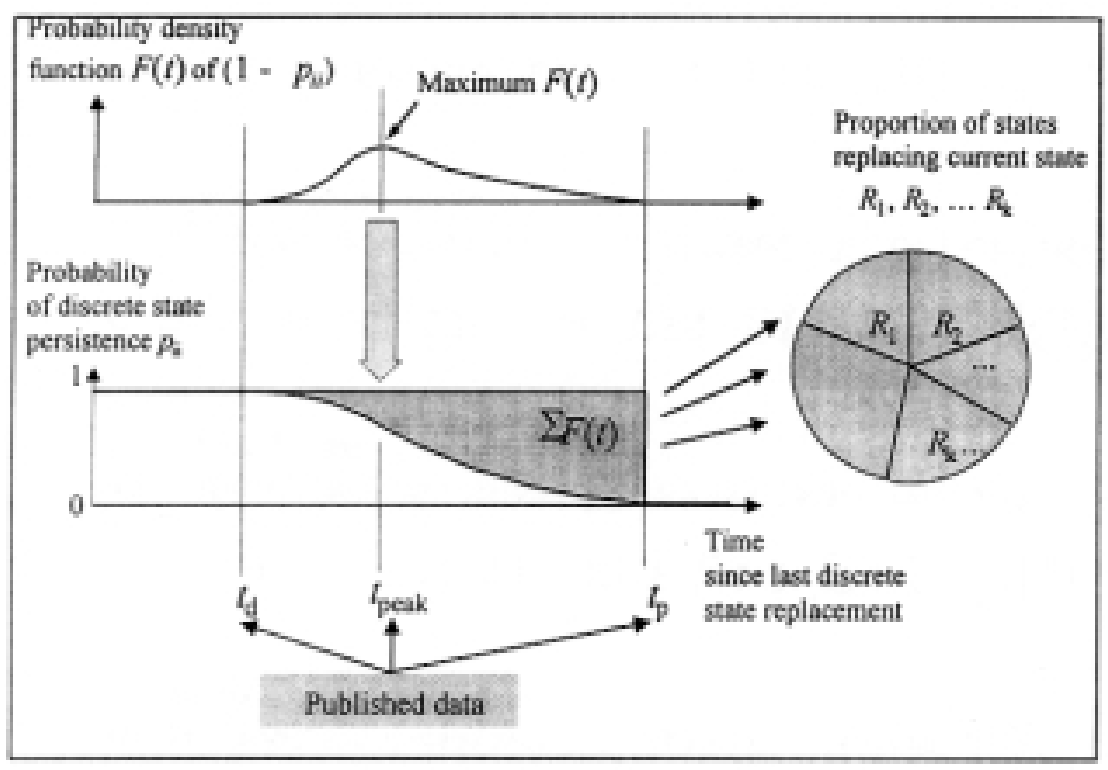

Fig. 3. Schematic representation of forest cover transitions: $t_{d}$-Time since establishment, when the replacement of one discrete state by another state begins; $t_{p}$ - Maximum persistence time of the discrete state; $t_{\text {peak }}$ - Time when rate of replacement of one discrete state by another reaches its maximum; $\Sigma F(t)$ - Cumulative values of probability density function $F(t) ; R_{1}, R_{2}$, .. $R_{k}$ - Proportion of states replacing current state.

eter estimation consists of the fitting $d_{i i}$ and $k_{i i}$ to minimize the deviation between the maximum of $h_{i j}(t)$ and $t_{\text {peak }}$ taken from the literature.

The proportion of other forest cover types replacing a given forest cover type during post-disturbance succession (e.g., as found in Sirois and Payette 1989, Viereck et al. 1993, Bergeron 2000) can be used to define resulting proportions $R_{j 1}, R_{j 2}, \ldots R_{j(n-1)}$ of discrete states after a transition from the current state $i$ into a set of states $j_{1}, j_{2}, \ldots j_{(n-1)}$. Here $n$ is the total number of discrete states in the model. Following Logofet and Lesnaya (2000), the transitions $p_{\mathrm{ij}}$ from state $i$ to states $j_{1}, j_{2}, \ldots j_{(n-1)}$ are constrained by proportions $R_{\mathrm{j} 1}, R_{\mathrm{j} 2}, \ldots R_{\mathrm{j}(\mathrm{n}-1)}$, and the condition of $R_{j 1}+R_{j 2}+\ldots+$ $R_{j(n-1)}=1$ during the transition period (Fig.3). Thus, for each discrete time interval $\Delta t, t \in\left[t_{\mathrm{d}},{ }_{\mathrm{p}}\right], p_{\mathrm{ij}}$ were found as:

$$
\begin{aligned}
& p_{i j}=R_{i}\left(1-p_{i i}\right), j=1,2, \ldots n-1, \text { and } R_{j 1}+R_{j 2}+\ldots+ \\
& R_{j(n-1)}=1
\end{aligned}
$$

Because the literature did not provide the details characterizing temporal behaviour of specific $p_{i j}$ transitions, it is difficult to consider time-dependence of each $p_{i j}$ transition.

Variables such as climatic zone (Rowe 1972, Sirois and Payette 1991), soil moisture (Viereck 1970, Bergeron and Dubuc 1989), and nutrient status (Viereck et al. 1983) can be used to stratify the transition probabilities by ecological site conditions.

This technique is appropriate for deriving transition probabilities from the mixture of semi-quantitative and quantitative successional data, where some references may report only part of the required information. More details on the use of published knowledge on succession in probabilistic models of forest cover change are discussed in Yemshanov and Perera (2002).

\section{Conclusions}

The literature provides only generalized data for describing succession as a discrete state replacement process, with discrete states identified by tree species dominance in the canopy at large scales. Although most published studies were conducted at the stand level, the data they presented were sufficient to define temporal boundaries of forest cover replacements, i.e., persis- tence of forest cover types, and the sequence of their replacement in the canopy. However, details on long-term succession (200 years or more) are rare, as are data on the effects of predisturbance composition on post-disturbance successional pathways. As a result, the published succession knowledge can be used for large-scale landscape modelling as a null model to be calibrated using multi-temporal spatial data (e.g., permanent sample plots, historical aerial surveys).

We summarized basic methods of incorporating published succession knowledge into probabilistic landscape models that represent data on succession as a transition probability matrix. This method may be used objectively to incorporate succession knowledge into models that simulate disturbances (e.g., fire, insect diseases, and harvest) in boreal landscapes, and perhaps to standardize input and output of landscape-scale forest cover change models.

\section{Acknowledgements}

We thank Wayne Bell, Kevin Weaver, Frank Schnekenburger, and three anonymous reviewers for their comments on previous drafts of this manuscript; and Lisa Buse for editorial review.

\section{References}

Abrams, M.D. 1991. Post-fire revegetation of jack pine sites in Michigan: An example of successional complexities. In High Intensity Fire in Wildlands. May 18-21, 1989, Tallahassee, Florida. pp. 197-209. Tall Timbers Res. Stn. Tallahassee, FL.

Abrams, M.D., D.G. Sprugel and D.I. Dickmann. 1985. Multiple successional pathways on recently disturbed jack pine sites in Michigan. For. Ecol. Manage. 10: 31-48.

Acevedo, M.F., D.L. Urban and M. Ablan. 1995. Transition and gap models of forest dynamics. Ecol. Appl. 5(4): 1040-1055.

Acevedo, M.F., D.L. Urban and H.F. Shugart. 1996. Models of forest dynamics based on roles of tree species. Ecol. Model. 87: 267-284. Alexander, M.E. and D.L. Euler. 1981. Ecological role of fire in the uncut boreal mixedwood forest. In R.D. Whitney and K.M. McClain (cochairs). Boreal Mixedwood Symposium. Sept. 16-18, 1980, Thunder Bay, ON. pp. 42-64. Can. For. Serv., Great Lakes For. Res. Cent., Sault Ste. Marie, ON. Inf. Rep. O-P-9. 
Arseneault, D. 2001. Impact of fire behavior on postfire forest development in a homogeneous boreal landscape. Can. J. For. Res. 31: 1367-1374.

Auclair, A.N. 1985. Postfire regeneration of plant and soil organic pools in a Picea mariana-Cladonia stellaris ecosystem. Can. J. For. Res. 15: 279-291.

Auclair, A.N. and F.C. Goff. 1974. Intraspecific diameter differentiation as a measure of species replacement potential. Can. J. For. Res. 4: 424-434.

Baker, W.L. 1989. A review of models of landscape change. Lands. Ecol. 2(2): 111-133.

Baker, W.L. 1993. Spatially heterogenous multi-scale response of landscapes to fire suppression. Oikos 66: 66-71.

Baker, W.L. 1999. Spatial simulation of the effects of human and natural disturbance regimes on landscape structure. In D.J. Mladenoff and W.L. Baker (Eds.). Spatial Modeling of Forest Landscape Change: Approaches and Applications. pp. 277-308. Cambridge Univ. Press, Cambridge, UK,

Baldwin, V.C., Jr. 1977. Regeneration following shelterwood cutting in a New Brunswick softwood stand. Can. For. Serv., Marit. For. Res. Cent., Fredericton, NB. Inf. Rep. M-X-76. 24 p.

Ball, W.J. and N.R. Walker. 1997. Stand development after partial cutting of mature mixed stands of white spruce and aspen in Manitoba. Can. For. Serv., North. For. Cent., Edmonton, AB. Inf. Rep. NOR-X-353. 42 p.

Balzter, H. 2000. Markov chain models for vegetation dynamics. Ecol. Model. 126: 139-154.

Baskerville, G.L. 1965. Deterioration and replacement in two overmature forest stands. Can. Dept. For., Ottawa, ON. Publ. No. 1125. 16 p.

Bella, I.E. and J.P. DeFranceschi. 1972. The effect of logging practices on the development of new aspen stands, Hudson Bay, Saskatchewan. Can. For. Serv., North. For. Res. Cent., Edmonton, AB. Inf. Rep. NOR-X-33. 20 p.

Bellefleur, P. 1981. Markov models of forest-type secondary succession in coastal British Columbia. Can. J. For. Res. 11: 18-29.

Bergeron, Y. 2000. Species and stand dynamics in the mixed woods of Quebec's southern boreal forest. Ecology 81(6): 1500-1516.

Bergeron, Y. and D. Charron. 1994. Postfire stand dynamics in a southern boreal forest (Quebec): A dendroecological approach. Ecoscience 1: 173-184.

Bergeron, Y. and P.R. Dansereau. 1993. Predicting the composition of Canadian southern boreal forest in different fire cycles. J. Veg. Sci. 4: 827-832.

Bergeron, Y. and M. Dubuc. 1989. Succession in the southern part of the Canadian boreal forest. Vegetatio 79: 51-63.

Bergeron, Y. and D. Gagnon. 1987. Age structure of red pine (Pinus resinosa Ait.) at its northern limit in Quebec. Can. J. For. Res. 17: 129-37.

Bergeron, Y. and B. Harvey. 1997. Basing silviculture on natural ecosystem dynamics: An approach applied to the southern boreal mixedwood forest of Quebec. For. Ecol. Manage. 92: 235-242.

Bertrand, L., L. Belanger and R.L. Beauregard. 1992. Regrowth of boreal stands of balsam fir with regeneration protection. Can. J. For. Res. 22: 1701-1711.

Black, R.A and L.C. Bliss. 1978. Recovery sequence of Picea mariana-Vaccinium uliginosum forests after burning near Inuvik, Northwest Territories, Canada. Can. J. Bot. 56: 2020-2030.

Bonan, G.B. and H.H. Shugart. 1989. Environmental factors and ecological processes in boreal forests. Ann. Rev. Ecol. Syst. 20: 1-28. Bonnor, G.M. and S. Magnussen. 1986. Inventory and growth predictions of the Petawawa forest. Can. For. Serv., Petawawa Nat. For. Inst., Chalk River, ON. Inf. Rep. RI-X-66. 30 p.

Brisson, J., Y. Bergeron and A. Bouchard. 1988. Les successions secondaries sur sites mésiques dans le Haut-Saint-Laurent, Québec, Canada. Can. J. Bot. 66: 1192-1203.

Bugmann, H.K.M. 1996. A simplified forest model to study species composition along climate gradients. Ecology 77: 2055-2074.
Bugmann, H.K.M. and P. Martin. 1995. How physics and biology matter in forest gap models. Clim. Change 29: 251-257.

Bugmann, H.K.M., X. Yan, M.T. Sykes, P. Martin, M. Lindner, P.V. Desanker and S.G. Cumming. 1996. A comparison of forest gap models: Model structure and behaviour. Clim. Change 34: 289-313. Burton, P. J. and S.G. Cumming. 1995. Potential effects of climatic change on some western Canadian forests, based on phenological enhancements to a patch model of forest succession. Water Air Soil Pollut. 82: 401-414.

Butson, R.G., P. Knowles and R.E. Farmer, Jr. 1987. Age and size structure of marginal, disjunct populations of Pinus resinosa. J. Ecol. 75: 685-692.

Carleton, T.J. 1982. The pattern of invasion and establishment of Picea mariana (Mill.) BSP into the subcanopy layers of Pinus banksiana Lamb. dominated stands. Can. J. For. Res. 12: 973-984. Carleton, T.J. and R.W. Arnup. 1993. Vegetation ecology of eastern white pine and red pine forests in Ontario. Ont. Min. Nat. Resour., Ont. For. Res. Inst., Sault Ste. Marie, ON. For. Fragment. Biodiv. Proj. Rep. 11. 282 p.

Carleton, T.J. and A.M. Gordon. 1992. Understanding old-growth red and white pine dominated forests in Ontario. Ont. Min. Nat. Resour., Ont. For. Res. Inst., Sault Ste. Marie, ON. For. Fragment. Biodiv. Proj. Rep. 2A. 124 p.

Carleton, T.J. and P.F. Maycock. 1980. Vegetation of the boreal forests south of James Bay: Non-centred component analysis of the vascular flora. Ecology 61: 1199-1212.

Carleton, T.J., R.K. Jones and G. Pierpoint. 1985. The prediction of understory vegetation by environmental factors for the purpose of site classification in forestry: An example from northern Ontario using residual ordination analysis. Can. J. For. Res. 15: 1099-1108.

Cayford, J.H. 1963. Some factors influencing jack pine regeneration after fire in southeastern Manitoba. Can. Dep. For. Rural Devel., For. Br. Dep. Publ. No. 1016. 19 p.

Cayford, J.H. and D.J. McRae. 1983. The ecological role of fire in jack pine forests. In R.W. Wein and D.A. MacLean, (eds.). The Role of Fire in Northern Circumpolar Ecosystems. pp. 183-199. Wiley and Sons, Chichester, UK.

Chambers, B. 1995. Successional trends by site type in northeastern Ontario. Ont. Min. Nat. Resour., NE Sci. Technol. Unit, Timmins, ON. NEST Tech. Rep. TR-009. 61 p.

Childress, W.M., C.M. Crisafulli and E.J. Rykiel, Jr. 1998. Comparison of Markovian matrix models of a primary successional plant community. Ecol. Model. 107: 93-102.

Chrosciewicz, Z. 1976. Burning for black spruce regeneration on a lowland cutover site in southeastern Manitoba. Can. J. For. Res. 6: 179-186.

Chrosciewicz, Z. 1983. Jack pine regeneration following postcut burning and seeding in southeastern Manitoba. Can. For. Serv., North. For. Res. Cent., Edmonton, AB. Inf. Rep. NOR-X-252. 11 p.

Chrosciewicz, Z. 1988. Forest regeneration on burned, planted, and seeded clear-cuts in central Saskatchewan. Can. For. Serv., North. For. Res. Cent., Edmonton, AB. Inf. Rep. NOR-X-293. 17 p. Clark, J.S. 1991. Disturbance and population structure on the shifting mosaic landscape. Ecology 72: 1119-1137.

Clayden, S. and A. Bouchard. 1983. Structure and dynamics of coniferlichen stands on rock outcrops south of Lake Abitibi, Quebec. Can. J. Bot. 61(3): 850-871.

Cogbill, C.V. 1985. Dynamics of the boreal forests of the Laurentian Highlands, Canada. Can. J. For. Res. 15: 252-261.

Cole, E.C., M. Newton and A. Youngblood. 1999. Regenerating white spruce, paper birch, and willow in south-central Alaska. Can. J. For. Res. 29: 993-1001.

Crowell, M. and B. Freedman. 1994. Vegetation development in a hardwood-forest chronosequence in Nova Scotia. Can. J. For. Res. 24: 260-271.

Cumming, S.G. 2001. Forest type and wildfire in the Alberta boreal mixedwood: What do fires burn? Ecol. Appl. 11 (1): 97-110. 
Cumming, S.G., F.K.A. Schmiegelow and P.J. Burton. 2000. Gap dynamics in boreal aspen stands: Is the forest older than we think? Ecol. Appl. 10: 744-759.

Dansereau, P.-R. and Y. Bergeron. 1993. Fire history in the southern boreal forest of northwestern Quebec. Can. J. For. Res. 23: 25-32.

Day, R.J. and J.V. Carter. 1990. Stand structure and successional development of the white and red pine communities in the Temagami forest. One of four reports in The Temagami White and Red Pine Ecology and Silviculture Study. Ont. Min. Nat. Resour., NE Reg., Sudbury, ON. 203 p.

Day, R.J. and E.M. Harvey. 1981. Forest dynamics in the boreal mixedwood. In R.D. Whitney and K.M. McClain (cochairs). Boreal Mixedwood Symposium. September 16-18, 1980, Thunder Bay, ON. pp. 29-41. Can. For. Serv., Great Lakes For. Res. Cent., Sault Ste. Marie, ON. Inf. Rep. O-P-9.

Day, R.J. and G.T. Woods. 1977. The role of wildfire in the ecology of jack and red pine forest in Quetico Provincial Park, Ontario. Ont. Min. Nat. Resour., Atikokan Distr., ON. Rep. No. 5. 79 p.

De Grandprè, L., D. Gagnon and Y. Bergeron. 1993. Changes in the understory of Canadian southern boreal forest after fire. J. Veg. Sci. 4: 803-810.

De Grandprè, L., J. Morisette and S. Gauthier. 2000. Longterm post-fire changes in the northeastern boreal forest of Quebec. J. Veg. Sci. 11: 791-800.

Deal, R.L. and W.A. Farr. 1994. Composition and development of conifer regeneration in thinned and unthinned natural stands of western hemlock and Sitka spruce in southeast Alaska. Can. J. For. Res. 24: 976-984.

Delaney, B.B. and M.J. Cahill. 1978. A pattern of forest types on ribbed moraines in eastern Newfoundland. Can. J. For. Res. 8: 116-120.

Dix, R.L. and J.M.A. Swan. 1971. The roles of disturbance and succession in upland forest at Candle Lake, Saskatchewan. Can. J. Bot. 49: 657-676.

Dyrness, C.T., L.A. Viereck and K. Van Cleve. 1986. Fire in taiga communities of interior Alaska. In Van Cleve, K., F.S. Chapin III, P.W. Flanagan, L.A. Viereck, and C.T. Dyrness (eds.). Forest Ecosystems in the Alaskan Taiga. pp. 74-86. Springer-Verlag, New York, NY.

Ellis, R.C. and C.R. Mattice. 1974. Stand development following pulpwood harvesting at the experimental lakes area in northwestern Ontario. Can. For. Serv., Great Lakes For. Res. Cent., Sault Ste. Marie, ON. Inf. Rep. O-X-207. 43 p.

Fiedler, C.E. and D.A. Lloyd. 1995. Autecology and synecology of western larch. In W.C. Schmidt and K.J. McDonald, (comps.). Ecology and Management of Larch Forests: A Look Ahead. Proceedings of an International Symposium. Whitefish, MT. pp. 118-122. USDA For. Serv., Intermtn. Res. Stn. Ogden, UT. Gen. Tech. Rep. INT-319. Flamm, R.O. and M.G. Turner. 1994. Alternative model formulations for a stochastic simulation of landscape change. Landsc. Ecol. 9: 37-46.

Flannigan, M.D., Y. Bergeron, O. Engelmark and B.M. Wotton. 1998. Future wildfire in circumboreal forests in relation to global warming. J. Veg. Sci. 9: 469-476.

Foote, M.J. 1983. Classification, description, and dynamics of plant communities after fire in the taiga of interior Alaska. USDA For. Serv., Res. Pap. PNW-307. 108 p.

Foster, D.R. 1985. Vegetation development following fire in Picea mariana (black spruce)- Pleurozium forests of south-eastern Labrador, Canada. J. Ecol. 73: 517-534.

Foster, D.R and G.A. King. 1986. Vegetation pattern and diversity in S.E. Labrador, Canada: Betula papyrifera (birch) forest development in relation to fire history and physiography. J. Ecol. 74: 465-483. Fraser, D.A. 1959. Nine years of observations on the condition of 241 yellow birch. Can. Dept. North. Aff. Nat. Resour., For. Br. Tech. Note No. 69. 24 p.
Galipeau, C.D. Kneeshaw and Y. Bergeron. 1997. White spruce and balsam fir colonization of a site in the southeastern boreal forest as observed 68 years after fire. Can. J. For. Res. 27: 139-147.

Gauthier, S., A. Leduc and Y. Bergeron. 1996. Forest dynamics modelling under natural fire cycles: A tool to define natural mosaic diversity for forest management. In R.A. Sims, I.G.W. Corns and K. Klinka (eds.). Global to Local: Ecological Land Classification. pp. 417-434. Kluwer Acad. Publ., Dordrecht, The Netherlands.

Gauthier, S., L. De Grandprè and Y. Bergeron. 2000. Differences in forest composition in two boreal forest ecoregions of Quebec. J. Veg. Sci. 11: 781-790.

Gauvin, C. and A. Bouchard. 1983. La vegetation forestière du Parc du Mont-Orford, Quebec. Can. J. Bot. 61: 1522-1547.

Gillis, M.D. and D.C. Leckie. 1996. Forest inventory update in Canada. For. Chron. 72 (2): 138-156.

Greene, D.F., J.C. Zasada, L. Sirois, D. Kneeshaw, H. Morin, L. Charron and M.-J. Simard. 1999. A review of the regeneration dynamics on North American boreal forest tree species. Can. J. For. Res. 29: 824-839.

Groot, A. and B.J. Horton. 1994. Age and size structure of natural and second-growth peatland Picea mariana stands. Can. J. For. Res. 24: 225-233.

Harris, A.S. 1972. Natural reforestation after logging on Afognak Island. USDA For. Serv., Pac. NW For. Range Exp. Stn., Portland, OR. Res. Note PNW-176. 11 p.

Harvey, B.D. and Y. Bergeron. 1989. Site patterns of natural regeneration following clear-cutting in northwestern Quebec. Can. J. For. Res. 19: 1458-1469.

Harvey, B.D., A. Leduc and Y. Bergeron. 1995. Early postharvest succession in relation to site type in the southern boreal forest of Quebec. Can. J. For. Res. 25: 1658-1672.

He, H.S. and D.J. Mladenoff. 1999. Spatially explicit and stochastic simulation of forest-landscape fire disturbance and succession. Ecology 80 (1): 81-99.

Heinselman, M.L. 1973. Fire in the virgin forests of the Boundary Waters canoe area, Minnesota. Quat. Res. 3: 329-382.

Heinselman, M.L. 1981. Fire and succession in the conifer forest of northern North America. In D.C. West, H.H. Shugart and D.B. Botkin, (eds.). Forest Succession: Concepts and Application. pp. 374-405. Springer-Verlag, New York, NY.

Hendrickson, O.Q. 1988. Biomass and nutrients in regenerating woody vegetation following whole-tree and conventional harvest in a northern mixed forest. Can. J. For. Res. 18: 1427-1436.

Hogg, E.H. 1994. Climate and the southern limit of the western Canadian boreal forest. Can. J. For. Res. 24: 1835-1845.

Holling, C.S. 1992. The role of forest insects in structuring the boreal landscape. In H.H. Shugart, R. Leemans and G.B. Bonan (Eds.). A Systems Analysis of the Global Boreal Forest. pp. 170-191. Cambridge Univ. Press, Cambridge, UK.

Horn, H.S. 1975. Markovian properties of forest succession. In M.L. Cody and J.M. Diamond, (eds.). Ecology and Evolution of Communities. pp. 196-211. Harvard Univ. Press, Cambridge, Ma.

Horn, H.S. 1981. Some causes of variety in patterns of secondary succession. In D.C. West, H.H. Shugart and D.B. Botkin, (eds.). Forest Succession: Concepts and Application. pp. 24-35. SpringerVerlag, New York, NY.

Host G.E., K.S. Pregitzer, C.W. Ramm, J.B. Hart and D.T. Cleland. 1987. Landform mediated differences in successional pathways among upland forest ecosystems in northwestern lower Michigan. For. Sci. 33: 445-457.

Howard, R.A. 1971. Dynamic Probabilistic Systems. Volume II: SemiMarkov and Decision Processes. Wiley and Sons, New York, NY. $530 \mathrm{p}$.

Jarvis, J.M. 1960. Forty-five years growth on the Goulais river watershed. Can. Dep. North. Affair. Nat. Resour., For. Br., Ottawa, ON. Tech. Note No. 84. 32 p. 
Jeglum, J.K. 1983. Changes in tree species composition in naturally regenerating strip clearcuts in shallow-soil upland black spruce. In R.W. Wein, R.R. Riewe and I.R. Methven (eds.). Conference Proceedings: Resources and Dynamics of the Boreal Zone. Assoc. Can. Univ. North. Stud., Thunder Bay, ON. pp. 180-193.

Jeglum, J.K. and A.N. Boissonneau. 1977. Air photo interpretation of wetlands, northern clay section, Ontario. Can. For. Serv., Great Lakes For. Res. Cent., Sault Ste. Marie, ON. 63 p.

Jin, K.-R. and Y. Wu. 1997. Boundary-fitted grid in landscape modeling. Landsc. Ecol. 12: 19-26.

Johnson, E.A. and G. Fryer. 1987. Historical vegetation change in the Kananaskis Valley, Canadian Rockies. Can. J. Bot. 65: 853-858. Johnson, E.A. and J.S. Rowe. 1977. Fire and vegetation change in the western subarctic. Can. Dept. Indian Aff. North. Develop., Ottawa, ON. Tech. Rep. ALUR 75-76-61. 58 p.

Johnson, E.A., K. Miyanishi and J.M.H. Weir. 1998. Wildfires in the western Canadian boreal forest: Landscape pattern and ecosystem management. J. Veg. Sci. 9: 603-610.

Johnstone, W.D. 1976. Ingress of lodgepole pine and white spruce regeneration following logging and scarification in west-central Alberta. Can. For. Serv., North. For. Res. Cent., Edmonton, AB. Inf. Rep. NOR-X-170. 12 p.

Karlin, S. 1968. A First Course in Stochastic Processes. Academic Press, New York, NY. 502 p.

Kasischke, E.S., N.L. Christensen and B.J. Stocks. 1995. Fire, global warming and the carbon balance of boreal forests. Ecol. Appl. 5: 437-451.

Kayll, A.J. 1968. The role of fire in the boreal forest of Canada. Can. Dept. For. Rural Devel., Petawawa For. Exp. Stn., Chalk River, ON. Res. Pap. PS-X-7. 15 p.

Kenkel, N.C. 1986. Structure and dynamics of jack pine stands near Elk Lake, Ontario: A multivariate approach. Can. J. Bot. 64: 486-497. Kenkel, N.C., P.R. Watson and P. Uhlig. 1998. Modelling landscape-level vegetation dynamics in the boreal forests of northwestern Ontario. Ont. Min. Nat. Resour., Ont. For. Res. Inst., Sault Ste. Marie, ON. For. Res. Rep. 148. 151 p.

Kienast, F., J. Fritschi, M. Bissegger and W. Abderhalden. 1999. Modeling successional patterns of high-elevation forests under changing herbivore pressure - responses at the landscape level. For. Ecol. Manage. 120: 35-46.

Kittredge, J.J. 1938. The interrelations of habitat, growth rate, and associated vegetation in the aspen community of Minnesota and Wisconsin. Ecol. Monogr. 8: 151-246.

Kneeshaw, D. and Y. Bergeron. 1996. Ecological factors affecting the abundance of advance regeneration in Quebec's southwestern boreal forest. Can. J. For. Res. 26: 888-898.

Kneeshaw, D. and Y. Bergeron. 1998. Canopy gap characteristics and tree replacement in the southeastern boreal forest. Ecology 79: 783-794.

Landhausser, S.M. and R.W. Wein. 1993. Postfire vegetation recovery and tree establishment at the Arctic treeline: Climate change - vegetation response hypotheses. J. Ecol. 81: 665-672.

Lavoie, L. and L. Sirois. 1998. Vegetation changes caused by recent fires in the northern boreal forest of eastern Canada. J. Veg. Sci. 9: 483-492.

Leduc, A., S. Gauthier and Y. Bergeron. 1995. Prevision de la composition d'une mosaique forestière naturelle soumise à un regime de feu: proposition d'un modele empirique pour le nord-ouest du Québec. In G. Domon and J. Falaedeau, (eds.). Landscape Ecology in Land Use Planning: Methods and Practice, Univ. Laval, SainteFoy, Q_. pp. 197-203. Polyscience Publ. Inc., Montreal, QC.

Lee, T.C., G.G. Judge and A. Zellner. 1970. Estimating the Parameters of the Markov Probability Model from Aggregate Time Series Data. North-Holland Publish. Co., Amsterdam, Holland. 255 p.

Lexer, M.J. and K. Hönninger. 2001. A modified 3D-patch model for spatially explicit simulation of vegetation composition in heterogeneous landscapes. For. Ecol. Manage. 144: 43-65.
Li, B.-L. 1995. Stability analysis of a nonhomogenous Markovian landscape model. Ecol. Model. 82: 247-256.

Li, H., J.F. Franklin, F.J. Swanson and T.A. Spies. 1993. Developing alternative forest cutting patterns: A simulation approach. Landsc. Ecol. 8: 63-75.

Logofet, D.O. and E.V. Lesnaya. 2000. The mathematics of Markov models: What Markov chains can really predict in forest succession. Ecol. Model. 126: 285-298.

Lutz, H.J. 1956. Ecological effects of forest fires in the interior of Alaska. USDA For. Serv., Tech. Bull. No. 1133. 121 p.

MacArthur, J.D. 1964. A study of regeneration after fire in the Gaspé region. Can. Dept. For., For. Res. Br. Publ. No. 1074. 20 p.

Mailly, D., J.P. Kimmins and R.T. Busing. 2000. Disturbance and succession in a coniferous forest of northwestern North America: Simulations with DRYADES, a spatial gap model. Ecol. Model. 127: 183-205.

Malanson, G.P. and D.M. Cairns. 1997. Effects of dispersal, population delays and forest fragmentation on tree migration rates. Plant Ecol. 131: 67-79.

Methven, I.R. 1973. Fire, succession, and community structure in a red and white pine stand. Can. For. Serv., Petawawa For. Exp. Stn., Chalk River, ON. Inf. Rep. PS-X-43. 18 p.

Mladenoff, D.J., M.A. White, J. Pastor and T.R. Crow. 1993. Comparing spatial pattern in unaltered old-growth and disturbed forest landscapes. Ecol. Appl. 3: 294-306.

Montague, T.G. and T.J. Givnish. 1996. Distribution of black spruce versus eastern larch along peatland gradients: Relationships to relative stature, growth rate, and shade tolerance. Can. J. Bot. 74: 1514-1532. Morneau, C. and S. Payette. 1989. Postfire lichen spruce woodland recovery at the limit of the boreal forest in northern Quebec. Can. J. Bot. 67: 2770-2782.

Moss, E.H. 1953. Forest communities in northwestern Alberta. Can. J. Bot. 31: 212-252.

Muller, M.R. and J.A. Middleton. 1994. A Markov model of land-use change dynamics in the Niagara Region, Ontario, Canada. Landsc. Ecol. 9: 151-157.

Neiland, B.J. and L.A. Viereck. 1977. Forest types and ecosystems. In North American Forest Lands at Latitudes North of 60 Degrees pp. 109-136. Sch. Agric. Res. Manage., Univ. Alaska, Fairbanks, AK. OMNR (Ontario Ministry of Natural Resources). 1996. Forest Management Planning Manual for Ontario's Crown Forests. Ont. Min. Nat. Res., Toronto, ON. 452 p.

OMNR (Ontario Ministry of Natural Resources). 1997. Silvicultural guide to managing for black spruce, jack pine and aspen on boreal ecosites in Ontario. Book III. Ecological and management interpretations for northeast site types. Version 1.1. Ont. Min. Nat. Resour., For. Manage Br., Sault Ste. Marie, ON. 254 p.

Paré, D. and Y. Bergeron. 1995. Above-ground biomass accumulation along a 230-year chronosequence in the southern portion of the Canadian boreal forest. J. Ecol. 83: 1001-1007.

Pastor, J. and D. Mladenoff. 1992. The southern boreal-northern hardwood forest border. In H.H. Shugart, R. Leemans, and G.B. Bonan, (eds.). A Systems Analysis of the Global Boreal Forest. pp. 216-240. Cambridge University Press, Cambridge, UK.

Pastor, J., Y. Cohen and R. Moen. 1999. Generation of spatial patterns in boreal forest landscape. Ecosystems 2: 439-450.

Payette, S. 1992. Fire as a controlling process in the North American boreal forests. In H.H. Shugart, R. Leemans and G.B. Bonan (Eds.). A Systems Analysis of the Global Boreal Forest. pp. 144-169. Cambridge Univ. Press, Cambridge, UK.

Payette, S. and L. Filion. 1985. White spruce expansion at the tree line and recent climatic change. Can. J. For. Res. 15: 241-251.

Payette, S., C. Morneau, L. Sirois and M. Desponts. 1989. Recent fire history of the northern Quebec biomes. Ecology 70: 656-673. Price, D.T. and M.J. Apps. 1995. The boreal forest transect case study: Global change effects on ecosystem processes and carbon dynamics in boreal Canada. Water Air Soil Pollut. 82: 203-214. 
Reid, D.E. 1974. Vegetation of the Mackenzie Valley. Part One. Vol. III. Can. Arctic Gas Biol. Rep. Ser., Arctic Gas Study Ltd., Calgary, AB. 149 p.

Rejmanek, M., C.E. Sasser and J.G. Gosselink. 1987. Modeling of vegetation dynamics in the Mississippi River deltaic plain. Vegetatio 69: 133-140.

Ritchie, J.C. 1956. The vegetation of northern Manitoba. I. Studies in the southern spruce forest zone. Can. J. Bot. 34: 523-561.

Ritchie, J.C. 1958. A vegetation map from the southern spruce forest zone of Manitoba. Geogr. Bull. (Canada) 12: 39-46.

Ritchie, J.C. 1961. Soil and minor vegetation of pine forests in southeast Manitoba. Can. Dept. For., For. Res. Div. Tech. Note No. 96. $21 \mathrm{p}$.

Roberts, M.R. and F.S. Gilliam. 1995. Patterns and mechanisms of plant diversity in forested ecosystems: Implications for forest management. Ecol. Appl. 5: 969-977.

Roberts, M.R. and G.R. Powell. 1988. Regeneration after clearcutting in the northern hardwood portion of the Nashwaak experimental watershed, New Brunswick. In C.W. Martin, C.T. Smith, and L.M. Tritton (eds.). New Perspectives on Silvicultural Management of Northern Hardwoods. pp. 85-90. USDA For. Serv., NE Res. Stn., Radnor, PA. Gen. Tech. Rep. NE-124.

Rowe, J.S. 1972. Forest Regions of Canada. Can. For Serv., Dept. Environ. Ottawa, ON. Publ. No. 1300. 172 p.

Sayn-Wittgenstein, L. 1978. Recognition of tree species on aerial photographs. Can. For. Serv., Ottawa, ON. 97 p.

Schmidt, T.L., J.S. Spencer, Jr. and M.H. Hansen. 1996. Old and potential old forests in the Lake States, USA. For. Ecol. Manage. 86: 81-96. Shafi, M.I and G.A. Yarranton. 1973. Diversity, floristic richness, and species evenness during a secondary (post-fire) succession. Ecology 54: 897-902.

Sims, R.A., H.M. Kershaw and G.M. Wickware. 1990. The autecology of major tree species in the North Central Region of Ontario. Can. For. Serv., Ont. Min. Nat. Resour., Sault Ste. Marie, ON. COFRDA Rep. 3302. NWOFTDU Tech. Rep. 48. 126 p.

Sirois, L. and S. Payette. 1989. Postfire black spruce establishment in subarctic and boreal Quebec. Can. J. For. Res. 19: 1571-1580.

Sirois, L. and S. Payette. 1991. Reduced postfire tree regeneration along a boreal forest-forest-tundra transect in northern Québec. Ecology 72: 619-627.

Spurr, S.H. and B.V. Barnes 1980. Forest Ecology, $3^{\text {rd }}$ ed. Wiley and Sons, New York, NY. 687 p.

Steneker, G.A. 1967. Growth of white spruce following release from trembling aspen. Can. Dep. For., For. Br., Ottawa, ON. Dep. Publ. No. 1183.18 p.

St-Pierre, H., R. Gagnon and P. Bellefleur. 1991. Distribution spatiale de la régénération après feu de l'épinette noire (Picea mariana) et du pin gris (Pinus banksiana) dans la forêt boréale, Réserve faunique Ashuapmushuan, Québec. Can. J. Bot. 69: 717-621.

St-Pierre, H., R. Gagnon and P. Bellefleur. 1992. Picea mariana and Pinus banksiana regeneration following fire in a boreal forest in Quebec. Can. J. For. Res. 22: 474-481.

Strang, R.M. 1973. Succession in unburned subarctic woodlands. Can. J. For. Res. 3: 140-143.

Thomas, P.A. and R.W. Wein. 1985. The influence of shelter and the hypothetical effect of fire severity on the postfire establishment of conifers from seed. Can. J. For. Res. 15: 148-155.

Timoney, K.P. and G. Peterson. 1996. Failure of natural regeneration after clearcut logging in Wood Buffalo National Park, Canada. For. Ecol. Manage. 87: 89-105.

Trabaud, L. and J.-F. Galtie. 1996. Effects of fire frequency on plant communities and landscape pattern in the Massif des Aspres (southern France). Landsc. Ecol. 11(4): 215-224.

Twolan-Strutt, L. and D.A. Welsh. 1997. Boreal forest succession: An intensive study of a mixedwood chronosequence. Nat. Resour. Can., Can. For. Serv., Great Lakes For. Cent., Sault Ste. Marie, ON. Tech. Rep. TR-31. 68 p.
UN-ECE/FAO. 2000. Forest Resources of Europe, CIS, North America, Australia, Japan and New Zealand. UN, New York, NY. Main Rep. Geneva Timber For. Study Pap. No. 17. ECE/TIM/SP/17. 467 p.

Urban, D.L. and H.H. Shugart. 1992. Individual-based models of forest succession. In D.C. Glenn-Lewin, R.K. Peet, and T.T. Veblen (eds.). Plant Succession: Theory and Prediction. pp. 249-292. Chapman and Hall, London, UK.

Urban, D.L., M.F. Acevedo and S.L. Garman. 1999. Scaling fine-scale processes to large-scale patterns using models derived from models: Meta-models. In D.J. Mladenoff and W.L. Baker (eds.). Spatial Modeling of Forest Landscape Change: Approaches and Applications. pp. 70-98. Cambridge Univ. Press, Cambridge, UK.

Usher, M.B. 1992. Statistical models of succession. In D.C. GlennLewin, R.K. Peet, and T.T. Veblen (eds.). Plant Succession: Theory and Prediction. pp. 215-248. Chapman and Hall. London, UK. Van Cleve, K. and L.A. Viereck. 1981. Forest succession in relation to nutrient cycling in the boreal forest of Alaska. In D.C. West, H.H. Shugart and D.B. Botkin (eds.). Forest Succession: Concepts and Application. pp. 185-211. Springer-Verlag, New York, NY.

Viereck, L.A. 1970. Forest succession and soil development adjacent to the Chena River in interior Alaska. Arct. Alp. Res. 2: 1-26. Viereck, L.A. 1973. Wildfire in the taiga of Alaska. Quat. Res. 3: 465-495.

Viereck, L.A. 1983. The effects of fire in black spruce ecosystems of Alaska and northern Canada. In R.W. Wein and D.A. MacLean (eds.). The Role of Fire in Northern Circumpolar Ecosystems. pp. 201-220. John Wiley and Sons. Chichester, UK.

Viereck, L.A. and C.T. Dyrness. 1979. Ecological effects of the Wicherman Dome fire near Fairbanks, Alaska. USDA For. Serv., Portland, OR. Gen. Tech. Rep. PNW-90. 71 p.

Viereck, L.A., C.T. Dyrness, K. Van Cleve and M.J. Foote. 1983. Vegetation, soils, and forest productivity in selected forest types in interior Alaska. Can. J. For. Res. 13: 703-720.

Viereck, L.A., K. Van Cleve, and C.T. Dyrness. 1986. Forest ecosystem distribution in the taiga environment. In K. Van Cleve, F.S. Chapin III, P.W. Flanagan, L.A. Viereck and C.T. Dyrness (eds.). Forest Ecosystems in the Alaskan Taiga. pp. 22-43. Springer-Verlag, New York, NY.

Viereck, L.A., C.T. Dyrness and M.J. Foote. 1993. An overview of the vegetation and soils of the floodplain ecosystems of the Tanana River, interior Alaska. Can. J. For. Res. 23: 889-898.

Wall, R.E. 1982. Secondary succession on recently cutover forest land in Nova Scotia. Can. For. Serv., Marit. For. Res. Cent., Fredericton, NB. Inf. Rep. M-X-133. 19 p.

Weinstein, D.A. and H.H. Shugart. 1983. Ecological modeling of landscape dynamics. In H.A. Mooney and M. Godron (eds.). Disturbance and Ecosystems: Components of Response. (Ecological Studies 44). pp. 29-45. Springer-Verlag, Berlin, Germany.

Weir, J.M.H. and E.A. Johnson. 1998. Effects of escaped settlement fires and logging on forest composition in the mixedwood boreal forest. Can. J. For. Res. 28: 459-467.

White, M.A. and D.J. Mladenoff. 1994. Old-growth forest landscape transitions from pre-European settlement to present. Landsc. Ecol. 9: 191-205.

Whitney, G.G. 1987. An ecological history of the Great Lakes forest of Michigan. J. Ecol. 75: 667-684.

Woods, G.T. and R.J. Day. 1976. The forests of Quetico Provincial Park: Based on a photogrammetric survey. Ont. Min. Nat. Resour., Atikokan Distr., Quetico Prov. Park, ON. Rep. No. 3.75 p. Woods, G.T. and R.J. Day. 1977. A summary of the fire ecology study of Quetico Provincial Park, Ontario. Ont. Min. Nat. Resour., Atikokan Distr., ON. Rep. No. 8. 39 p.

Yarie, J. 1981. Forest fire cycle and life tables: A case study from interior Alaska. Can. J. For. Res. 11: 554-562.

Yarie, J. 1983. Environmental and successional relationships of the forest communities of the Porcupine river drainage, interior Alaska. Can. J. For. Res. 13: 721-728. 
Yemshanov, D.G. and A.H. Perera. 2001. Modelling boreal forest succession at broad scales: A North American bibliography. Ont. Min. Nat. Resour., Ont. For. Res. Inst., Sault Ste. Marie, ON. For. Res. Inf. Pap. No. 146. 46 p.

Yemshanov, D.G. and A.H. Perera. 2002. A spatially explicit stochastic model to simulate boreal forest cover transitions: general structure and properties. Ecol. Model. 150 (1-2): 189-209.

Youngblood, A. 1995. Development patterns in young coniferhardwood forests of interior Alaska. J. Veg. Sci. 6 (2): 229-236.

Zasada, J.C., R.A. Norum, C.E. Teutsch and R. Densmore. 1987. Survival and growth of planted black spruce, alder, aspen and willow after fire on black spruce/feathermoss sites in interior Alaska. For. Chron. 63: 84-88.

Zasada, J.C., T.L. Sharik and M. Nygren. 1992. The reproductive process in boreal forest trees. In H.H. Shugart, R. Leemans and G.B. Bonan (eds.). A Systems Analysis of the Global Boreal Forest. pp. 85-125. Cambridge Univ. Press, Cambridge, UK.
Zhang, Q., K.S. Pregitzer and D.D. Reed. 1999. Catastrophic disturbance in the presettlement forests of the Upper Peninsula of Michigan. Can. J. For. Res. 29: 106-114.

Zipperer, W.C., R.L. Burgess, and R.D. Nyland. 1990. Patterns of deforestation and reforestation in different landscape types in central New York. For. Ecol. Manage. 36: 103-117.

Zoladeski, C. and P.F. Maycock. 1990. Dynamics of the boreal forest in northwestern Ontario. Am. Midl. Nat. 124: 289-300.

Zoltai, S.C. 1975. Structure of subarctic forests on hummocky permafrost terrain in northwestern Canada. Can. J. For. Res. 5: 1-9.

Appendix 1. Summary of available literature on forest succession in the North American boreal biome and adjacent sub-boreal zones relevant to predicting forest land cover change

\begin{tabular}{|c|c|c|c|c|c|c|}
\hline Author(s) & Year & Location & $\begin{array}{l}\text { Disturbance } \\
\text { type }\end{array}$ & $\begin{array}{l}\text { Average } \\
\text { length of } \\
\text { succession } \\
\text { (years) }\end{array}$ & $\begin{array}{c}\text { Unique } \\
\text { stages } \\
\text { (number) }\end{array}$ & $\begin{array}{c}\text { Groups based } \\
\text { on site } \\
\text { conditions } \\
\text { (number) }\end{array}$ \\
\hline \multicolumn{7}{|c|}{ Landscape-level spatial scale at forest type study resolution } \\
\hline Schmidt et al. & 1996 & Generalized to Lake States (Michigan, Minnesota) & $\begin{array}{l}\text { Natural } \\
\text { ageing }\end{array}$ & 13 & 1 & 8 \\
\hline Weinstein and Shugart & 1983 & $\begin{array}{l}\text { Southern boreal forest zone, generalized to } \\
\text { Lake States (Michigan, Minnesota) }\end{array}$ & $\begin{array}{l}\text { Natural } \\
\text { ageing }\end{array}$ & 250 & 2 & 3 \\
\hline \multicolumn{7}{|c|}{ Forest type spatial scale at forest type study resolution } \\
\hline Gauthier et al. & 1996 & Les Basses-Terres d'Amos, Quebec & Fire & 220 & 9 & 4 \\
\hline Viereck et al. & 1986 & Alaska & Fire & Non-specific & Non-specific ${ }^{1}$ & 3 \\
\hline \multicolumn{7}{|c|}{ Tree stand spatial scale at forest type study resolution } \\
\hline Abrams & 1991 & Northern lower Michigan & Fire & Non-specific & 4 & 1 \\
\hline Bergeron and Danserau & 1993 & Lake Abitibi, Quebec & Fire & 220 & 8 & 1 \\
\hline Dyrness et al. & 1986 & Generalized to Interior Alaska & Fire & 200 & 6 & 2 \\
\hline Foster & 1985 & Southeastern Labrador & Fire & Non-specific & 3 & 1 \\
\hline Johnson and Rowe & 1977 & Caribou Range, Northwest Territory & $\begin{array}{l}\text { Fire and } \\
\text { natural ageing }\end{array}$ & $\begin{array}{r}50 \\
2\end{array}$ & 8 & 23 \\
\hline Pastor and Mladenoff & 1992 & $\begin{array}{l}\text { Generalized to Great Lakes boreal hardwood } \\
\text { zone }\end{array}$ & $\begin{array}{l}\text { Natural } \\
\text { ageing }\end{array}$ & Non-specific & 5 & Non-specific \\
\hline Payette et al. & 1989 & Northern Quebec & Fire & 60 & 6 & 1 \\
\hline Reid & 1974 & Mackenzie Valley, Alaska & Fire & 120 & 6 & 2 \\
\hline Ritchie & 1958 & Northern Manitoba & Fire & Non-specific & 5 & Non-specific \\
\hline \multicolumn{7}{|c|}{ Tree stand spatial scale at species study resolution } \\
\hline Abrams et al. & 1985 & Northern lower Michigan & $\begin{array}{l}\text { Fire and } \\
\text { natural ageing }\end{array}$ & 35 & Non-specific & 1 \\
\hline Alexander and Euler & 1981 & Wabigoon Lake, Ontario & Fire & Non-specific & $3-4$ & 5 \\
\hline Auclair & 1985 & Schefferville, Quebec & Fire & 140 & 7 & 1 \\
\hline Auclair and Goff & 1974 & $\begin{array}{l}\text { Generalized to southern boreal mixedwood, } \\
\text { Wisconsin }\end{array}$ & $\begin{array}{l}\text { Natural } \\
\text { ageing }\end{array}$ & Non-specific & 3 & 1 \\
\hline Baldwin & 1977 & Edmundston, New Brunswick & Harvest & 10 & 3 & 5 \\
\hline Ball and Walker & 1997 & Manitoba Escarpment, Manitoba & Harvest & 40 & 2 & 6 \\
\hline Baskerville & 1965 & Green River Watershed, New Brunswick & Harvest & 10 & 1 & 2 \\
\hline Bergeron & 2000 & Lake Duparquet, Quebec & $\begin{array}{l}\text { Fire and } \\
\text { natural ageing }\end{array}$ & 225 & 11 & 1 \\
\hline Bergeron and Charron & 1994 & Lake Duparquet, Quebec & $\begin{array}{l}\text { Fire and } \\
\text { natural ageing }\end{array}$ & 75 & 5 & 38 \\
\hline Bergeron and Dubuc & 1989 & Lake Duparquet, Quebec & Fire & 300 & 6 & 4 \\
\hline Bergeron and Gagnon & 1987 & Lake Duparquet, Quebec & Fire & 200 & 2 & 22 \\
\hline Black and Bliss & 1978 & Inuvik, NWT & $\begin{array}{l}\text { Harvest and } \\
\text { natural ageing }\end{array}$ & Non-specific & Non-specific & 4 \\
\hline Bonnor and Magnussen & 1986 & Algonquin Park, Ontario & Harvest & 5 & 3 & 1 \\
\hline Brisson et al. & 1988 & Upper St. Lawrence area, Quebec & $\begin{array}{l}\text { Natural } \\
\text { ageing }\end{array}$ & 20 & 1 & 1 \\
\hline Butson et al. & 1987 & Lake Nipigon, Ontario & Harvest & Non-specific & Non-specific & 1 \\
\hline Carleton & 1982 & Swastika, Timiskaming district, Ontario & Fire & 30 & 1 & 1 \\
\hline Carleton and Arnup & 1993 & Eastern Ontario & Fire & Non-specific & 3 & 2 \\
\hline
\end{tabular}




\begin{tabular}{|c|c|c|c|c|c|c|}
\hline \multicolumn{7}{|l|}{ Appendix 1. Continued } \\
\hline Carleton and Maycock & 1980 & Northern and central Ontario & $\begin{array}{l}\text { Natural } \\
\text { ageing }\end{array}$ & Non-specific & 2 & Non-specific \\
\hline Cayford and McRae & 1983 & Generalized to North American boreal zone & Fire & Non-specific & 2 & Non-specific \\
\hline Chrosciewicz & 1976 & Southeastern Manitoba & Fire & Non-specific & Non-specific & 1 \\
\hline Chrosciewicz & 1983 & Southeast of Winnipeg, Manitoba & $\begin{array}{l}\text { Fire and } \\
\text { harvest }\end{array}$ & 10 & 1 & 3 \\
\hline Clayden and Bouchard & 1983 & Lake Abitibi, Quebec & $\begin{array}{l}\text { Natural } \\
\text { ageing }\end{array}$ & Non-specific & 2 & 3 \\
\hline Cogbill & 1985 & Laurentian Highlands, Quebec & $\begin{array}{l}\text { Harvest and } \\
\text { natural ageing }\end{array}$ & 200 & 2 & 8 \\
\hline Crowell and Freedman & 1994 & Kings County, Nova Scotia & $\begin{array}{l}\text { Natural } \\
\text { ageing }\end{array}$ & 75 & 4 & 1 \\
\hline Danserau and Bergeron & 1993 & Lake Abitibi, Quebec & Fire & Non-specific & Non-specific & Non-specific \\
\hline Day and Carter & 1990 & Temagami forest, Ontario & $\begin{array}{l}\text { Fire and } \\
\text { natural ageing }\end{array}$ & 260 & Non-specific & 11 \\
\hline Day and Harvey & 1981 & Generalized to boreal mixedwood zone & Fire & 125 & 4 & Non-specific \\
\hline Day and Woods & 1977 & Quetico Provincial Park & Fire & 210 & 4 & 2 \\
\hline De Grandprè et al. & 2000 & North Shore region, Quebec & Fire & 225 & 4 & Non-specific \\
\hline Delaney and Cahill & 1978 & Avalon Peninsula, Newfoundland & Fire & 50 & 1 & 1 \\
\hline Dix and Swan & 1971 & Candle Lake, Saskatchewan & $\begin{array}{l}\text { Natural } \\
\text { ageing }\end{array}$ & 100 & 2 & 4 \\
\hline Fiedler and Lloyd & 1995 & Generalized to Western Canada & $\begin{array}{l}\text { Natural } \\
\text { ageing }\end{array}$ & Non-specific & Non-specific & Non-specific \\
\hline Foote & 1983 & South of Yukon River, Interior Alaska & Fire & 200 & 6 & 2 \\
\hline Foster and King & 1986 & Southeastern Labrador & Fire & 110 & Non-specific & 45 \\
\hline Galipeau et al. & 1997 & Abitibi’s Hebecourt township, Quebec & Fire & 68 & 3 & 4 \\
\hline Gauthier et al. & 2000 & Abitibi-Lake Matagami Lowlands, Quebec & Fire & 225 & 10 & 2 \\
\hline Gauvin and Bouchard & 1983 & Mount Orford Park, Quebec & $\begin{array}{l}\text { Natural } \\
\text { ageing }\end{array}$ & Non-specific & Non-specific & 8 \\
\hline Greene et al. & 1999 & Generalized to boreal North America & $\begin{array}{l}\text { Harvest and } \\
\text { natural ageing }\end{array}$ & Non-specific & Non-specific & Non-specific \\
\hline Groot and Horton & 1994 & Northern Clay section, Iroquois Falls, Ontario & $\begin{array}{l}\text { Natural } \\
\text { ageing }\end{array}$ & Non-specific & Non-specific & 40 \\
\hline Harris & 1972 & Afognak Island, Alaska & Harvest & 20 & Non-specific & Non-specific \\
\hline Harvey and Bergeron & 1989 & Lake Abitibi, Quebec & $\begin{array}{l}\text { Natural } \\
\text { ageing }\end{array}$ & 6 & 1 & 4 \\
\hline Harvey et al. & 1995 & Clay Belt, Quebec & $\begin{array}{l}\text { Natural } \\
\text { ageing }\end{array}$ & 8 & 1 & 9 \\
\hline Heinselman & 1973 & Boundary Waters Canoe area, Minnesota & Fire & 200 & 1 & 2 \\
\hline Heinselman & 1981 & $\begin{array}{l}\text { Generalized to North American southern } \\
\text { boreal biome }\end{array}$ & Fire & Non-specific & Non-specific & Non-specific \\
\hline Hendrickson & 1988 & Petawawa Research Forest, Ontario & Harvest & 4 & 1 & 2 \\
\hline Jarvis & 1960 & Goulais River Watershed, Ontario & Fire & 46 & 4 & 2 \\
\hline Johnstone & 1976 & Hinton, Alberta & Harvest & 10 & Non-specific & 1 \\
\hline Kayll & 1968 & Generalized to Canadian boreal zone & Fire & Non-specific & Non-specific & Non-specific \\
\hline Kenkel & 1986 & Elk Lake, Ontario & $\begin{array}{l}\text { Natural } \\
\text { ageing }\end{array}$ & Non-specific & Non-specific & 3 \\
\hline Kenkel et al. & 1998 & Northwestern Ontario & $\begin{array}{l}\text { Natural } \\
\text { ageing }\end{array}$ & 250 & 5 & 12 \\
\hline Kittredge & 1938 & Generalized to southern boreal mixedwood & $\begin{array}{l}\text { Fire and } \\
\text { natural ageing }\end{array}$ & Non-specific & Non-specific & Non-specific \\
\hline Kneeshaw and Bergeron & 1996 & Lake Duparquet, Quebec & Fire & 200 & 7 & 1 \\
\hline Landhausser and Wein & 1993 & Inuvik, NWT & Fire & 7 & 1 & 1 \\
\hline Lavoie and Sirois & 1998 & Chisasibi region, Quebec & Fire & 6 & 3 & 4 \\
\hline Leduc et al. & 1995 & Lake Duparquet, Quebec & $\begin{array}{l}\text { Natural } \\
\text { ageing }\end{array}$ & 220 & 8 & 4 \\
\hline MacArthur & 1964 & Gaspè Region, Quebec & Fire & 20 & Non-specific & 1 \\
\hline Montague and Givnish & 1996 & Northern Wisconsin & $\begin{array}{l}\text { Natural } \\
\text { ageing }\end{array}$ & 250 & Non-specific & 4 \\
\hline Morneau and Payette & 1989 & Hudson Bay area, Quebec & Fire & 250 & 6 & 1 \\
\hline Moss & 1953 & Northwestern Alberta & Fire & Non-specific & 4 & Non-specific \\
\hline Neiland and Viereck & 1977 & Alaska & Fire & 220 & 4 & Non-specific \\
\hline OMNR & 1997 & Generalized to Ontario boreal biome & Harvest & 100 & 5 & 19 \\
\hline Ritchie & 1956 & Northern Manitoba & $\begin{array}{l}\text { Fire and } \\
\text { natural ageing }\end{array}$ & Non-specific & Non-specific & Non-specific \\
\hline Roberts and Powell & 1988 & Nashwaak watershed, New Brunswick & Harvest & 6 & 1 & 16 \\
\hline Shafi and Yarranton & 1973 & Clay Belt, Ontario & Fire & 50 & Non-specific & Non-specific \\
\hline Sims et al. & 1990 & Generalized to northwest Ontario & $\begin{array}{l}\text { Fire and } \\
\text { natural ageing }\end{array}$ & Non-specific & Non-specific & Non-specific \\
\hline Sirois and Payette & 1991 & Northern Quebec & Fire & Non-specific & Non-specific & Non-specific \\
\hline Steneker & 1967 & Riding Mountain, Manitoba & Harvest & 10 & Non-specific & Non-specific \\
\hline St-Pierre et al. & 1991 & Reserve Ashuapmushuan, Quebec & Fire & 5 & Non-specific & Non-specific \\
\hline St-Pierre et al. & 1992 & Lake Saint-Jean, Quebec & Fire & 5 & Non-specific & Non-specific \\
\hline
\end{tabular}




\begin{tabular}{|c|c|c|c|c|c|c|}
\hline \multicolumn{7}{|l|}{ Appendix 1. Continued } \\
\hline Strang & 1973 & Lower Mackenzie River, NWT & Fire & Non-specific & Non-specific & Non-specific \\
\hline Timoney and Peterson & 1996 & Peace River Lowlands, Alberta & Harvest & Non-specific & Non-specific & Non-specific \\
\hline Twolan-Strutt and Welsh & 1997 & Manitouwadge, Ontario & Harvest & 200 & 6 & 1 \\
\hline Van Cleve and Viereck & 1981 & Tanana River, Alaska & Fire & 300 & 5 & 3 \\
\hline Viereck & 1973 & Alaska & $\begin{array}{l}\text { Fire and } \\
\text { natural ageing }\end{array}$ & 200 & 3 & Non-specific \\
\hline Viereck and Dyrness & 1979 & Yukon-Tanana Uplands, Alaska & Fire & 5 & 3 & 1 \\
\hline Viereck et al. & 1993 & Tanana River, Alaska & $\begin{array}{l}\text { Natural } \\
\text { ageing }\end{array}$ & Non-specific & Non-specific & Non-specific \\
\hline Wall & 1982 & Nova Scotia & Harvest & 6 & 3 & 1 \\
\hline Weir and Johnson & 1998 & Prince Albert National Park, Saskatchewan & Fire & 90 & 1 & 1 \\
\hline Whitney & 1987 & Northern lower Michigan & $\begin{array}{l}\text { Natural } \\
\text { ageing }\end{array}$ & 140 & 1 & 2 \\
\hline Woods and Day & 1976 & Quetico Provincial Park, Ontario & Fire & Non-specific & $2-4$ & Non-specific \\
\hline Woods and Day & 1977 & Quetico Provincial Park, Ontario & Fire & 250 & Non-specific & Non-specific \\
\hline Yarie & 1981 & Fort Yukon, Alaska & Fire & 200 & Non-specific & Non-specific \\
\hline Yarie & 1983 & Porcupine River drainage area, Alaska & $\begin{array}{l}\text { Natural } \\
\text { ageing }\end{array}$ & Non-specific & Non-specific & Non-specific \\
\hline Youngblood & 1995 & Fairbanks-Big Delta, Alaska & Fire & 60 & 4 & 1 \\
\hline Zoladeski and Maycock & 1990 & Northwestern Ontario & $\begin{array}{l}\text { Natural } \\
\text { ageing }\end{array}$ & 150 & $8-11$ & 7 \\
\hline Zoltai & 1975 & Mackenzie River Valley, NWT & Fire & 220 & 2 & 1 \\
\hline \multicolumn{7}{|c|}{ Individual-based spatial scale at species study resolution } \\
\hline Bella and DeFranceschi & 1972 & Hudson Bay, Saskatchewan & Harvest & 5 & 4 & 6 \\
\hline Bertrand et al. & 1992 & Matane, Quebec & $\begin{array}{l}\text { Harvest and } \\
\text { natural ageing }\end{array}$ & Non-specific & 1 & 1 \\
\hline Cayford & 1963 & Sandilands Forest Reserve, Manitoba & Harvest & 5 & 4 & 1 \\
\hline Chrosciewicz & 1988 & Candle Lake, Saskatchewan & Harvest & 8 & 1 & 14 \\
\hline Cole et al. & 1999 & Fort Richardson, Alaska & Harvest & 5 & 1 & 4 \\
\hline Deal and Farr & 1994 & Prince Wales Island, Alaska & Harvest & 20 & 2 & 1 \\
\hline Ellis and Mattice & 1974 & Northwestern Ontario & Harvest & 13 & 3 & 1 \\
\hline Fraser & 1959 & Petawawa Model Forest, Ontario & Harvest & 9 & 9 & 8 \\
\hline Kneeshaw and Bergeron & 1998 & Lake Duparquet, Quebec & $\begin{array}{l}\text { Fire and } \\
\text { natural ageing }\end{array}$ & 234 & Non-specific & Non-specific \\
\hline Payette and Filion & 1985 & Hudson Bay-Richmond Gulf, Quebec & $\begin{array}{l}\text { Fire and } \\
\text { natural ageing }\end{array}$ & Non-specific & Non-specific & 1 \\
\hline
\end{tabular}

${ }^{1}$ Study reports generalized data 